\title{
Description of a contourite depositional system on the Demerara Plateau: Results from geophysical data and sediment cores
}

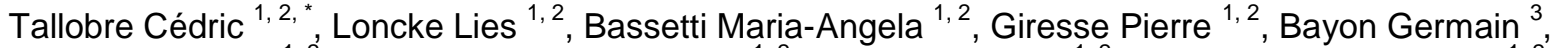 \\ Buscail Roselyne ${ }^{1,2}$, Durrieu De Madron Xavier ${ }^{1,2}$, Bourrin François ${ }^{1,2}$, Vanhaesebroucke Marc ${ }^{1,2}$, \\ Sotin Christine ${ }^{1,2}$, Iguanes Scientific Party
}

\footnotetext{
${ }^{1}$ Univ. Perpignan Via Domitia, Centre de Formation et de Recherche sur les Environnements Méditerranéens (CEFREM), UMR 5110, 52 Avenue Paul Alduy, 66860 Perpignan, France

${ }^{2}$ CNRS, Centre de Formation et de Recherche sur les Environnements Méditerranéens (CEFREM), UMR 5110, 52 Avenue Paul Alduy, 66860 Perpignan, France

${ }^{3}$ IFREMER, Unité de Recherche Géosciences Marines, 29280 Plouzané, France

* Corresponding author : Cédric Tallobre, email address : cedric.tallobre@univ-perp.fr
}

\begin{abstract}
:
The Demerara Plateau, belonging to the passive transform margin of French Guiana, was investigated during the IGUANES cruise in 2013. The objectives of the cruise were to explore the poorly-known surficial sedimentary column overlying thick mass transport deposits as well as to understand the factors controlling recent sedimentation. The presence of numerous bedforms at the seafloor was observed thanks to newly acquired IGUANES bathymetric, high resolution seismic and chirp data, while sediment cores allowed the characterization of the deposits covering the mass transport deposits. Modern oceanographic conditions were determined in situ, using mooring monitoring over a 10-month period. Our data indicate the presence of a Contourite Depositional System along the Demerara Plateau, most likely related to bottom current activity of the North Atlantic Deep Water (NADW). However, at the regional scale, large longitudinal waves parallel the NADW flow. Their shape and orientation seem to be inherited from interactions between bottom currents and paleomorphologies expressed at the top of mass transport deposits. Their evolution is possibly driven by the intensity of bottom current activity that might have changed over time. Overall, this work presents an integrated approach combining seismic and sedimentological evidence to study the processes at the origin of contourite formation in the Demerara Plateau. Other regional factors, such as local slope values and slope instability, also control sedimentation.
\end{abstract}




\section{Highlights}

- A Contourite Depositional System (CDS) is present on the Demerara Plateau. - The marginal plateau forms a bathymetry high promoting the formation of contourite. The formation of longitudinal waves seems to be associated to this contourite.

Keywords : Marginal plateau, Contourite, Comet tail, Demerara Plateau

\section{Introduction}

Contourites correspond to deposits generated by deep ocean currents and are typically associated with graded bioturbated sediment sequences (Faugères et al., 1984; Gonthier et al., 1984; Stow et al., 2002a; Rebesco et al., 2014; Hanebuth et al., 2015). The concept of contourites was introduced in the 1960s (Heezen and Hollister, 1964; Hollister, 1967) and mainly refers to deposits related to deep thermohaline ocean circulation. Today, the definitionembraces all types of sediment deposited or substantially reworked by the action of persistent bottom currents (Stow et al., 2002b). Contourites are typically part of a larger sedimentary structure, usually called a "Contourite Depositional System" or CDS (Rebesco and Camerlenghi, 2008). The study of contourite deposits may provide information on environmental and oceanographic conditions and a large community is today interested in these sedimentological archives to (1) investigate the variability of paleoceanographic conditions in connection with the paleoclimate, or (2) to better understand the role of currents in sediment transport/erosion in the construction of continental margins.

The sedimentary characteristics of the western margin of South America are well known thanks to the large number of existing studies. The Brazil (Faugères et al., 1993; Massé et al., 1998; Viana, 1998) and Argentina margins (Faugères et al., 1993; Hernández-Molina et al., 2009; Hernández-Molina et al., 2010) have been well documented and a number of studies have described the presence of contourites and the different elements that compose a CDS. In contrast, the northeastern margin of South America is poorly documented. The first 
description of along-slope processes on the continental rise of the western equatorial Atlantic Ocean was first proposed by Damuth and Kumar (1975), who demonstrated the significant role of contour currents on the depositional processes in this area. Belonging to the South America northeastern margin, the Demerara marginal plateau (hereinafter referred to as DP) occupies a specific place: it forms a long continental salient off the coasts of Surinam and French Guiana and is emplaced between the Central and Equatorial Atlantic oceans. The plateau stretches about $380 \mathrm{~km}$ long along the coast and is $\sim 250 \mathrm{~km}$ wide from the shelf break, with water depths ranging from $150 \mathrm{~m}$ to $4500 \mathrm{~m}$. Mercier de Lépinay et al, (personal communication) have shown that such marginal plateaus typically forms along transform margins (example of the Demerara and Guinean plateaus, Falkands and Agulhas marginal plateaus, Vøring plateau). Their specific structure and bathymetric characteristics may exert a control on sediment processes and guide deep currents.

The marginal DP has been recently studied on the basis of geophysical data (Loncke et al., 2009; Pattier et al., 2013). Those analyses highlight the fact that this continental margin was affected by significant slope instability apparently controlled by the structure and the steepness of the transform border of the plateau (Pattier et al., 2013).

New data (sediment cores and high resolution geophysical data) were acquired along the DP during the IGUANES survey (2013) in order to better understand the sedimentary processes ongoing along such marginal plateau. This new high resolution dataset highlights the role of contourite processes that seem to interfere with slope instability on the DP. This new dataset suggests that the impact of contourite processes has probably been underestimated up to now on the DP.

The aim of this study is to better describing recent sedimentary processes and the role of contourite processes along the DP, based on new multidisciplinary dataset (high resolution geophysics, sediment cores, mooring). It allows us discussing about the interplay between 
oceanic conditions at the origin of the contourites and slope instability processes. The structural control that may exert along such type of marginal plateau is also discussed.

\section{Regional setting}

\subsection{Geological setting}

The DP is located at the junction between the central and equatorial Atlantic Ocean, off the northern South American margin (French Guiana and Suriname; Fig. 1). It forms a promontory (380 km long and $220 \mathrm{~km}$ wide) which extends the continental platform seawards, with water depths ranging from $150 \mathrm{~m}$ to $4500 \mathrm{~m}$ (Fig. 2). The DP is bounded on the north by a steep continental slope, which corresponds to an abrupt transform-derived continent-ocean transition zone and two divergent continent-ocean transitions respectively on the west and east. Before the opening of the equatorial Atlantic Ocean, the DP was connected to the West African Guinea Plateau. Oceanic opening and structuration of the DP occurred in two phases. (1) During the Lower Jurassic, the opening of the central Atlantic Ocean led to the formation of a divergent segment on the western edge of the DP. At this time, the Guinea Plateau was still connected to the DP (Klitgord and Schouten, 1986; Gouyet, 1988; Unternehr et al., 1988; Benkhelil et al., 1995). (2) During the Lower Cretaceous, the equatorial Atlantic opening occurred in a transform mode, allowing the separation of the DP and Guinea Plateau. This Cretaceous stage is characterized by a strike-slip movement along the northern edge of the DP and divergent movement along its eastern edge (Gouyet, 1988; Unternehr et al., 1988). Different features (faults, folds, thrusts) illustrate this Mesozoic tectonic activity (Gouyet, 1988; Basile et al., 2013). These deformations are sealed by a post-transform unconformity, itself overlain by horizontal to slightly tilted Cretaceous to recent sediments.

The stratigraphy of the sedimentary units of the DP is known from industrial borehole G2 investigations (Gouyet, 1988) and from ODP Expedition 207 (Erbacher, 2004; Mosher et al., 2007). The oldest sedimentary sequence studied in wells/drills relates to Albian sediments 
rich in organic matter and the Cenomanian-Turonian black shales, followed by Late Cretaceous and Paleogene clays rich in calcareous nannofossils (chalk) (Gouyet, 1988; Mosher et al., 2007; Pattier, 2013). The later deposits correspond to Miocene argillaceous and chalky sediments. Sedimentation was later dominated by terrigenous clays and fine deposits associated with a thick Neogene progradational wedge during the Neogene. Very low sedimentation rates have been recorded for the Late Pleistocene and Holocene (Erbacher, 2004; Mosher et al., 2007; Ingram et al., 2011; Pattier, 2013). Since the Oligocene, the external DP has been particularly affected by slope instabilities with a major sediment slope failure headscarp still visible in the bathymetry (Fig. 3) and probably regularly reactivated (Loncke et al., 2009; Pattier, 2013; Pattier et al., 2013; Pattier et al., 2015). MTDs (Mass Transport Deposit) pile up for a thickness of nearly $600 \mathrm{~m}$ in the distal DP (Pattier et al., 2013). The major sediment slope failure headscarp is parallel to the transform margin, suggesting strong structural control (Pattier et al., 2013). Post-MTD sedimentation is heterogeneous on the DP. Above the MTDs, and mainly on MTD highs, some depressions have been described and interpreted as pockmarks (Loncke et al., 2009; Pattier, 2013; Pattier et al., 2013). Seismic wipeouts on chirp profiles suggest fluid flow on the DP (Loncke et al., 2009). Under overpressure conditions, these fluids can decrease frictional forces and, when associated with the slope gradient of the transform margin, generate slides (Pattier et al., 2013). In addition to these downslope processes, Damuth and Kumar (1975) described alongslope processes on the continental rise of the western equatorial Atlantic, linked to the bottom currents associated to the NADW, which impact sedimentary dispersal.

\subsection{Oceanographic setting}

The Atlantic Meridional Overturning Circulation (AMOC) is the current system in the Atlantic Ocean which controls the heat transport (Apel, 1988; Talley et al., 2011; Survey, 2012). It is characterized by the flow of warm and saline surface waters from tropical area 
toward the North Atlantic and a return southward flow of cold deep waters (Apel, 1988; Talley et al., 2011; Survey, 2012). The water column in the equatorial Atlantic is divided into three main superficial, intermediate and deep water masses (Fig. 2 and Table 1). The surface layer is composed of Tropical Surface Water (TSW) originating from the North Tropical Gyre (Garfield, 1990; Tsuchiya et al., 1994). Coastal upwelling with a strong seasonal variability can be observed along the coast inside this surface layer (Gibbs, 1980). The intermediate layer is composed of relatively fresh AntArctic Intermediate Water (AAIW) formed in the southern ocean (Reid, 1989; Peterson and Stramma, 1991; Tsuchiya et al., 1994; Stramma and Schott, 1999). The deep waters is made of cold and salty water masses, the North Atlantic Deep Water (NADW) derived from the North Atlantic and Arctic Seas, and the colder, less saline AntArctic Bottom Water (AABW) formed around Antarctica (Reid, 1989; Molinari et al., 1992; Johns et al., 1993; Tsuchiya et al., 1994; Hogg, 1997; Mauritzen et al., 2002). The main characteristics of these water masses are summarized in Table 1, and their position across the bathymetry of the DP are depicted in Fig. 2. Most of the DP is under the influence of the NADW, whereas its upper part is at the transition between the AAIW and the NADW and its lower part is at the transition between the NADW and the AABW.

\section{Material \& methodology}

\subsection{Geophysical data}

The geophysical dataset acquired during the IGUANES cruise includes EM122 multibeam echosounder data (bathymetry, backscatter imagery and water column) and chirp data. Highresolution 72-channel seismic data were also acquired during the IGUANES cruise (acquisition speed c.5 kn, the source is made of 6 GI-Guns). In this paper, only four highresolution seismic lines (Fig. 3) have been used to illustrate the geometry of sedimentary units. Seismic data were processed using Ifremer QC-Sispeed software. First, a quality control of navigation and seismic data was performed. Then, SEGD data was converted to SEGY and 
binning, stack and migration were performed. The maximum vertical resolution of seismic data is $4 \mathrm{~m}$ for the high resolution 72 channel acquisition. The chirp data (Sub-bottom profiler, chirp mode, band width $1800-5300 \mathrm{~Hz}$ ) were processed (quality control and concatenation) using Ifremer Subop software. The chirp profiles have an average vertical resolution of 20 to $30 \mathrm{~cm}$ and a horizontal resolution of $20 \mathrm{~m} \mathrm{(500} \mathrm{m} \mathrm{water} \mathrm{depth)} \mathrm{to} 60 \mathrm{~m}$ (4000 m water depth). An isopach map of recent sedimentation on the whole plateau (last $30 \mathrm{~m}$ ) has been built using chirp data. To do this, the yellow reflector ("yellow horizon" hereafter) was picked and propagated laterally on all profiles. It corresponds to the deepest reflector reached by core sampling.

Multibeam data were processed using Ifremer Caraibes software. A $25 \mathrm{~m}$ resolution grid was obtained. All these data were integrated in Q-GIS software for comparison and analysis. All maps have been projected in UTM zone 22 in the WGS84 geodetic system.

\subsection{Sediment cores}

Twenty piston cores were recovered for geochemical analyses and sedimentology. These cores were collected on the Plateau between $1200 \mathrm{~m}$ and $5000 \mathrm{~m}$ water depth (Fig. 3). Most cores were collected near depressions (i.e. suspected pockmarks) at the seafloor (Loncke et al., 2009; Pattier et al., 2013). In this study, we focus on one sediment core: IG-KSF-11 (6 m long) collected in the upper part of the DP at $2366 \mathrm{~m}$ of water depth $\left(07^{\circ} 51.085^{\prime} \mathrm{N}\right.$, $052^{\circ} 29.025^{\prime} \mathrm{W}$ ) in bedded sediments outside a depression and near a sedimentary high (Fig. $4)$.

\subsubsection{Sediment properties}

The sediment core was visually described after splitting. Samples were later collected at steps of $10 \mathrm{~cm}$ for analyses. The bulk sediment was dried and sieved to separate the fraction $>63 \mu \mathrm{m}$. The sand fraction was calculated by weighting the $>63 \mu \mathrm{m}$ residue with respect to the 
initial dry weight. Glauconite grains were sorted from the sand fraction using a binocular microscope and a thin section was realized in the glauconite-rich bed (collected in core IGKS-01 at 157-160 cm depth) and observed under a transmitted light microscope. The detailed analyses presented here come from core IG-KSF-11, but the observation of several cores was used to identify the different sediment facies described below.

\subsubsection{Age assessment}

Five ${ }^{14} \mathrm{C}$ dates in core IG-KSF-11 were obtained by means of the Accelerator Mass Spectrometer (AMS) of Poznań Radiocarbon Laboratory, using the monospecific assemblage of well-preserved planktic foraminifer Globigerinioides sp. Measured ages were converted to calendar years using Calib 7.0.4 with the Marine 09 calibration curve (Reimer et al., 2013).

\subsubsection{Geochemical analyses}

Semi-quantitative geochemical analyses (element count rates) were performed along core IG-KSF-11 with an X-Ray Fluorescence (XRF) core scanner operated at both $10 \mathrm{kV}$ and 30 $\mathrm{kV}$ and with a $1 \mathrm{~cm}$ of sampling interval. In this study, $\mathrm{Ca} / \mathrm{Fe} \mathrm{Ti} / \mathrm{Ca}$ and $\mathrm{Si} / \mathrm{Ca}$ ratios have been used to provide information about the composition of the sediment, in particular to discriminate between relative contributions from terrigenous versus biogenic components. The calcareous grains in the fraction above $63 \mu \mathrm{m}$ were shown to be of biogenic origin, although the presence of detrital components in the fraction above $63 \mu \mathrm{m}$ cannot be excluded. Calcium is considered as being mainly controlled by biogenic components, while $\mathrm{Si}, \mathrm{Fe}$ and Ti are used as proxies for the terrigenous fraction mainly component of oxides and silicate minerals (Arz et al., 1998; Jansen et al., 1998).

Organic matter content was measured on the samples from core IG-KSF-11. Total carbon $\left(\mathrm{C}_{\mathrm{t}}\right)$, organic carbon $\left(\mathrm{C}_{\text {org }}\right)$ and total nitrogen $\left(\mathrm{N}_{\mathrm{t}}\right)$ concentrations were obtained on freezedried sediment subsamples by combustion in an automatic C-N analyzer (Elementar 
VarioMax). Organic carbon values were obtained after removing carbonate carbon by progressive and controlled acidifications with $1 \mathrm{M} \mathrm{H}_{3} \mathrm{PO}_{4}$ and $2 \mathrm{M} \mathrm{HCl}$ successively, and left overnight at $40{ }^{\circ} \mathrm{C}$ (Cauwet et al., 1990). Precision measurements were about 5\% DW for $\mathrm{C}_{\text {org }}, 10 \% \mathrm{DW}$ for $\mathrm{N}_{\mathrm{t}}$ and $1 \% \mathrm{DW}$ for $\mathrm{C}_{\mathrm{t}}$. The calcium carbonate content was calculated from mineral carbon $\left(\mathrm{C}_{\mathrm{t}}-\mathrm{C}_{\text {org }}\right)$ using the molecular mass ratio $\left(\mathrm{CaCO}_{3}: \mathrm{C}=100: 12\right)$.

\subsection{Mooring data}

A short mooring, with instruments located between $14 \mathrm{~m}$ and $19 \mathrm{~m}$ above the seafloor, was deployed at $3000 \mathrm{~m}$ depth off French Guiana on the DP $\left(08^{\circ} 01.080^{\prime} \mathrm{N}, 52^{\circ} 21.331^{\prime} \mathrm{W}\right)$. It was equipped with an Aanderaa RCM8 current meter, a RBR virtuoso with a Seapoint turbidity sensor at $880 \mathrm{~nm}$, and an SBE37 SMP with pressure, temperature and conductivity sensors. This mooring was deployed on May 11, 2013 and recovered on March 25, 2014. The current meter had a sampling period of 30 minutes, whereas the other probes had a sampling period of 6 minutes. The latter data were averaged over 30 -minute periods after processing the records. The turbidity is given in NTU and can be approximately converted into suspended particulate matter (SPM) concentration using the linear relationship valid for low NTU value $(<5$ NTU):

SPM $[\mathrm{mg} / \mathrm{l}]=3.76 \times$ Turbidity [NTU] (Durrieu de Madron, unpublished data).

\section{Results}

\subsection{Geophysical data}

\subsubsection{Bathymetry}

The bathymetry illustrates the main characteristics of the lower DP (Fig. 3). On its shallower part ( 1400 m of water depth), a linear NW-SE slope failure headscarp forms an abrupt incision delimiting a stable upper domain from an instable domain (Pattier et al., 2013). Further down the slope failure headscarp, the plateau deepens gently towards the 
continental slope. At $51^{\circ} 50 \mathrm{~W}, 8^{\circ} 05 \mathrm{~N}$, a seamount-like structure can be observed, which corresponds to an outcropping basement high associated with the transform continent-ocean transition zone (Basile et al., 2013).

The slope failure headscarp is composed of coalescent NW-SE failures. In places, arcuate slope failures initiate along the main headscarp $\left(7^{\circ} 45 \mathrm{~N}-52^{\circ} 35 \mathrm{~W}\right.$ for example). Between the slope failure headscarp and the basement high, hundreds of depressions are observed on the seafloor. They are all elongated towards the southeast and resemble giant flute casts (Fig. 4.A). They show an outstanding head and an elongated depression. The length of these objects ranges between $400 \mathrm{~m}$ and $4500 \mathrm{~m}$, and the width between $260 \mathrm{~m}$ and $1800 \mathrm{~m}$. Their depth is comprised between $7 \mathrm{~m}$ and $50 \mathrm{~m}$.

Some of these elongated depressions align in a SW-NE direction, perpendicular to the slope (Fig. 3 \& 4.A).

A significant part of the plateau is marked by NW-SE waves parallel to the slope. These objects are not homogeneous and have a length between 3.1 and $15 \mathrm{~km}$, a height between 0.75 and $22.50 \mathrm{~m}$ and a wavelength between 180 and $1795 \mathrm{~m}$. The elongated depressions mostly occur inside wave fields (Fig. 4.A and 5.A for example).

\subsubsection{High resolution seismic profiles and chirp data}

On the high resolution seismic profiles and chirp data, the recent sedimentation (the uppermost 100 m approximately) shows an alternation of bedded undulated, and acoustically transparent and chaotic deposits (Fig. 5 and 6). The acoustically transparent deposits systematically show erosive bases and rippled or chaotic tops (Fig. 4B and 5B and 6 at the scale of seismic data, Fig. 5C at the scale of Chirp data). They have been interpreted as Mass Transport Deposits (MTDs) by previous authors(Loncke et al., 2009; Pattier et al., 2013). The top of these MTDs is, in some cases, very undulated (Fig. 4.B, 5.B \& 6). The gray MTDs can be assigned to the Late Miocene/Early Pliocene (LM/EP) using correlation with age data 
obtained from boreholes and published in Pattier et al. (2013) and Pattier et al. (2015). On top of the MTDs, the unit thickness of the bedded sediment is variable. In some cases, asymmetric waves can be observed (Fig. $5 \& 6$ ). These waves are characterized by an average height of $8.84 \mathrm{~m}$ and $875 \mathrm{~m}$ of wavelength on the Figure 5, and $4.85 \mathrm{~m}$ of height and $856 \mathrm{~m}$ of wavelength on the Figure 6.A. Seismic data illustrate the asymmetric morphology of the waves. The position of successive crests, as well as the thickening of their lee side compared to their stoss side, attests to an upslope migration (Fig. 6.A for example). The lateral extension of the LM/EP (Pattier, 2013; Pattier et al., 2013) and more recent MTDs are mapped, and superimposed those maps on the map of the seafloor (Fig. 3). This map shows that waves occur on the whole plateau above the LM/EP MTD, except along the slope failure headscarp and where post-LM/EP MTDs (in purple) have occurred and smoothed the undulated seafloor (Fig. 3 \& 6).

When observing the seismic expression of the elongated depressions which appear in the bathymetry as "giant flute casts", it appears that the head of those features mostly corresponds to the top of nearly outcropping MTDs, as already observed by Pattier et al. (2013). In other configurations (Fig. 4B), these depressions appear above isolated sedimentary highs which are characterized by internal chaotic reflectors. Core IG-KS-11 was collected near such a sedimentary high, which outcrops on the seafloor as shown on chirp profile IG-053 (transparent to chaotic acoustic body on Fig. 4C).

The isopach map (Fig. 7) shows that recent sediments (yellow reflector propagated on chirp profiles, Fig. 4.C and 5.C) reach an average thickness of $18 \mathrm{~m}$ upslope of the main slope failure headscarp. Downslope of the slope failure headscarp to $2400 \mathrm{~m}$ of water depth, the sediment thickness decreases to zero in places, except along small patchy accumulations (Fig. 7). These patches are elongated, with a NW-SE axis. This 20 to $30 \mathrm{~km}$ wide depleted zone roughly parallels the NW-SE slope failure headscarp. Going downslope, between 2400 and 
$3500 \mathrm{~m}$ water depth, sediment thicknesses increase again (13-20 m), forming a roughly NWSE elongated accumulation that drastically thickens towards the south $(33 \mathrm{~m})$, in correspondence with the divergent border of the DP (Fig. 7). Another NW-SE depleted zone appears below $3500 \mathrm{~m}$ water depth, towards the northern transform border of the DP.

Chirp profiles illustrate the fact that the slope failure area (Fig. 8. and 9.B) is in most cases incised. They also illustrate the internal structure of patchy accumulations (Fig. $8 \&$ 9.A-B) which are composed of bedded sediments with sometimes intercalated transparent bodies (Fig. 8). Two main configurations are observed. (1) These sedimentary accumulations thin downslope (Fig. 9.B) and their internal geometry is characterized by downlapping clinoforms. The thickest part of these masses is plastered against the slope failure headscarp that forms a concave shape (visible on Fig. $7 \&$ 9.A). (2) Other patchy sedimentary accumulations are disconnected from the slope failure headscarp. They form downslope substratum highs not overlain by recent MTDs (Fig. 9.C).

\subsection{Mooring measurements}

Results of the mooring data are shown in Figure 10. Currents are clearly anisotropic and primarily oriented along-slope toward the southeast (the major axis of the current ellipse is $124^{\circ} \mathrm{N}$, Fig. 11). The velocity ranges between 0 and $32.5 \mathrm{~cm} / \mathrm{s}$ (Fig. 10.B), with an average of $9.5 \mathrm{~cm} / \mathrm{s}$ and a mean direction of $128^{\circ} \mathrm{N}$ (Fig. 11). Potential temperature ranges between 2.2 and $2.6{ }^{\circ} \mathrm{C}$, and salinity between 34.89 and 34.93 , which is characteristic of NADW (Fig. 10.C). These two parameters evolve in parallel and inversely to the velocity. When the velocity is high $(>25 \mathrm{~cm} / \mathrm{s})$, significant temperature and salinity drops generally concur with velocity increases. It is noteworthy that in mid-January 2014, the large drops of temperature $\left(\sim 0.25^{\circ} \mathrm{C}\right)$ and salinity $(\sim 0.02)$ resulted from a brief ( 3-days) current reversal. During the second inversion of the current direction to return to the initial conditions the flow was momentary southward and induced an upslope advection of deeper and colder water. The 
turbidity of the bottom water is relatively low ( $<1 \mathrm{NTU})$ with an average around $0.03 \mathrm{NTU}$ (Fig. 10.E) and turbidity fluctuations are uncorrelated with the increase of current speed (Fig. 10.D).

A spectral analysis for the along-slope and across-slope components was performed from the current meter data (Fig. 12). It presents two peaks of energy that correspond to the semidiurnal tidal signal. The stronger peak corresponds to the M2 constituent (principal lunar semidiurnal with a period of 12.42 hours) and the second peak corresponds to the S2 constituent (principal solar semidiurnal with a period of 12 hours).

\subsection{Core analysis}

\subsubsection{Sediment characteristics of core $I G-K S F-11$}

The 6-meter-long core IG-KSF-11 was retrieved next to an elongated depression in a wave field (Fig. 4) in an area with low sedimentary accumulation (only $10 \mathrm{~m}$ thick on the isopach map, Fig. 7). The site is located upstream of a depression with respect to the presumed direction of the current (NW-SE), as shown in the seismic profile (IG-053 HR, Fig. 4.B).

Core IG-KSF-11 consists of greenish-gray mud. The mud has a mottled appearance caused by strong bioturbation (Fig. 13). The sediment contains $\sim 5-6 \%$ of sand made of biogenic and mineral components. Bioclastic grains consist of fragments of foraminifera (planktonic and benthic), urchins, pteropods, scaphopods, ostracods, sponges, bivalves and gastropods. Authigenic glauconite and pyrite are found in the whole core with different concentrations. A great number of centimeter-thick green beds are found interbedded between 400 and $500 \mathrm{~cm}$

(Fig. 13). They are rich in glauconite (the highest content in the total sample being $13 \%$ and $94 \%$ in the sandy fraction). Graded bedding sequences are present with coarsening upward followed by fining upward (between $450-500 \mathrm{~cm}$ and $0-50 \mathrm{~cm}$ on Fig. 13). 
Sandy beds present a high $\mathrm{Ca} / \mathrm{Fe}$ ratio and low $\mathrm{Ti} / \mathrm{Ca}-\mathrm{Si} / \mathrm{Ca}$ ratios (Fig. 13). The sandy fraction is rich in biogenic components (mainly foraminifera), as illustrated by a carbonate content which varies between 5\% and 35\% d.w (dry weight). The beds that are poorer in sand (as at 200-204 cm core depth) show low $\mathrm{Ca} / \mathrm{Fe}$ and high Ti/Ca and Si/Ca ratios. Finally, two beds (at 420-455 cm and 475-500 cm depth) are notable, being rich in sand and glauconite grains with a high $\mathrm{Si} / \mathrm{Ca}$ ratio and low $\mathrm{Ca} / \mathrm{Fe}$ ratio.

The interval between $0-90 \mathrm{~cm}$ is the richer in carbonate and biogenic sand (up to $20 \%$ of biogenic sand). The high content in carbonate $(20-36 \%$ d.w.) is due to the high content of biogenic components. The $\mathrm{C}_{\text {org }}$ content generally shows low values, ranging between 0.16 and $0.54 \%$ d.w. (with a low average value of $0.40 \%$ d.w.). The amount of $\mathrm{N}_{\mathrm{t}}$, which varies between $0.04 \%$ and $0.15 \%$ d.w., is proportionally more abundant than $\mathrm{C}_{\mathrm{org}}$. As expected, the organic matter content $\left(\mathrm{C}_{\mathrm{org}}, \mathrm{N}_{\mathrm{t}}\right)$ is higher in muddy levels. Throughout the core, the muddy sequence between 90 and $280 \mathrm{~cm}$ is characterized by higher amounts of $\mathrm{C}_{\text {org }}$ and $\mathrm{N}_{\mathrm{t}}$ with mean values of $0.45 \%$ d.w. and $0.11 \%$ d.w., respectively. The $\mathrm{C} / \mathrm{N}$ ratio oscillates between 3.6 and 8.3 with an average value of 5.5. A $\mathrm{C} / \mathrm{N}$ ratio between 4 and 6 corresponds to the value expected for protein-rich organic matter formed in oceanic surface waters (Bordovskiy, 1965b, c, a; Müller, 1977; Monoley and Field, 1991).

\subsubsection{Facies classification}

The sedimentological facies in the DP (Table 3) are defined on the basis of sand content, biogenic and mineralogical content, sedimentary structures, and in the case of core IG-KSF11 (Fig. 13) they can be associated with the sediment composition determined by organic matter content and semi-quantitative elemental composition based on the X-ray fluorescence:

- F1, Glauconite facies: this consists of a sand facies rich in glauconite (dominant component up to $94 \%$ in the sandy fraction) and biogenic debris (sand content $>5 \%$ ). Generally, the glauconite facies corresponds to low $\mathrm{Ca} / \mathrm{Fe}$ and high $\mathrm{Ca} / \mathrm{Ti}$ and $\mathrm{Si} / \mathrm{Ca}$ 
ratios. Around $350 \mathrm{~cm}$ core depth, a bed characteristic of this $\mathrm{F} 1$ facies has a high $\mathrm{Ca} / \mathrm{Fe}$ ratio and lower $\mathrm{Ca} / \mathrm{Ti}$ and $\mathrm{Si} / \mathrm{Ca}$ ratios. This paradox is explained by more abundant biogenic carbonate grains with respect to glauconite. F1 has mostly low $\mathrm{N}_{\mathrm{t}}$ content.

- F2, Foraminifera sandy facies: sand content is $>5 \%$ and consists of biogenic debris mixed with glauconite (between $0.1 \%$ and $1 \%$ of glauconite grains in the sandy fraction) and pyrite. This facies correlates with high $\mathrm{Ca} / \mathrm{Fe}$, low $\mathrm{N}_{\mathrm{t}}$ and $\mathrm{C}_{\text {org }}$ contents.

- F3, Foraminifera-bearing mud facies: it consists of fine mud with some biogenic sand grains ( $1 \%$ to $5 \%$ of sand content) with few glauconite grains $(>0.1 \%$ of the sandy fraction). Relatively high $\mathrm{Ti} / \mathrm{Ca}$ and $\mathrm{Si} / \mathrm{Ca}$ indicate the dominance of a terrigenous fraction, while the low $\mathrm{Ca} / \mathrm{Fe}$ can be related to low biogenic carbonate content. Consequently, the values of $\mathrm{N}_{\mathrm{t}}$ and $\mathrm{C}_{\text {org }}$ are high.

- F4, Muddy facies: it is the finest facies, poor in sand grains $(<1 \%)$ and glauconite becomes rare $(<0.01 \%$ of the sandy fraction) or missing. It encompasses the higher value of $\mathrm{Ti} / \mathrm{Ca}$ and $\mathrm{Si} / \mathrm{Ca}$, which corresponds to very low content in biogenic grains. At the same time, $\mathrm{N}_{\mathrm{t}}$ and $\mathrm{C}_{\text {org }}$ contents are the highest.

\subsubsection{Radiocarbon ages}

The ${ }^{14} \mathrm{C}$ ages are presented in Table 2, indicating a time interval comprised between approximately $14 \mathrm{ky}$ cal. BP and $43 \mathrm{ky} \mathrm{cal}$ BP, between 0 and $452 \mathrm{~m}$. However, in the lower part of the core an inversion is observed (29 ky cal. BP at $600 \mathrm{~cm}$ of depth). We cannot develop a complete age model with these data.

\section{Interpretation and discussion}

\subsection{Characterization of modern oceanographic conditions on the DP}

The results confirm that the study area at $3000 \mathrm{~m}$ depth on the DP is directly influenced by the NADW, one component of the DWBC, which flows southeastwardly along the 
continental slope (Fig. 10). These observations are consistent with previous hydrological and hydro-dynamic observations collected in the same region (Molinari et al., 1992).

The low value of the turbidity (Fig. 10.D) can be explained by the fact that the mooring on the DP is distant from the main Amazon and Orinoco rivers and distant from the coast, limiting continental terrigenous supply. These low values were expected and are in agreement with the values measurements close to the seafloor of the Atlantic Ocean (Gardner et al., 1985; McCave, 1986).

The near-bottom current direction has the same orientation as the different bedforms observed on the DP (depressions that resemble giant flute casts and longitudinal waves), suggesting the strong impact of currents on the shaping of the bottom morphology. The modern current speed $(9.5 \mathrm{~cm} / \mathrm{s}$ in average and $32.5 \mathrm{~cm} / \mathrm{s}$ in maximum) is sufficiently high to transport/erode bottom sediment (Stow et al., 2009).

The January event, with the lowermost salinity and temperature values, might correspond to the transit of a meander or an eddy at the mooring site, which are both common features in deep western boundary currents (Hogg and Brechner Owens, 1999; Weatherly et al., 2002). The observed salinity (34.91-34.92) and potential temperature $\left(2-2.1^{\circ} \mathrm{C}\right.$, Fig. 10.C) are characteristic of the lower NADW (Table 1), and illustrate an occasional up-slope incursion of lower NADW at $3000 \mathrm{~m}$ depth on the DP.

\subsection{The ${ }^{14} \mathrm{C}$ dates issue}

The dating reversals constitute a major problem in this study. Logically, we assume that the ${ }^{14} \mathrm{C}$ dates obtained at 0 and $130 \mathrm{~cm}$ are valid measurements, whereas from $313 \mathrm{~cm}$ to $582 \mathrm{~cm}$ (Table 2) they are virtually beyond the ${ }^{14} \mathrm{C}$ limit (>40 ky). The bottom of the core (600 cm depth) presents a reversal, confirmed by a double measurement. The origin of these reversals is unknown for the moment. Thus, the ${ }^{14} \mathrm{C}$ dates at $313,452,582$ and $600 \mathrm{~cm}$ depth 
are here considered with great caution. In addition, we observe "rejuvenation" from $452 \mathrm{~cm}$ to the bottom of the core that is difficult to explain using the available data. A possible explanation might be contamination of dated material by fluid flows via the pockmarks as proposed in Loncke et al. (2009), Pattier (2013), and in (Pattier et al., 2013). Indeed, the core is located at the top of an area characterized by a transparent and hyperbolic acoustic facies (Fig. 4). This bathymetric relief is observed in the seismic profiles but its origin is not clear. Nonetheless, considering the general context, fluid flows could have been expelled in this area, possibly generating a radiocarbon dilution derived by an uptake of ${ }^{14} \mathrm{C}$-free carbon from non-atmospheric $\mathrm{CO}_{2}$ (Aharon et al., 1997).

Another hypothesis is reworking by bottom currents that might remobilize sediment. The circulation of the deep Atlantic Ocean during glacial stages appears to be different to the interglacials because it is controlled by freshwater fluxes in the North Atlantic (LynchStieglitz et al., 2007). During phases of slow NADW formation (glacial), the northwards penetration of deep and cold Antarctic waters might induce increased bottom water winnowing and possibly supply sediment and debris from older sediments that could cause ${ }^{14} \mathrm{C}$ age eldering. This scenario is described in the southernmost Atlantic Ocean (Scotia Sea) by Howe and Pudsey (1999). Similar conditions can be imagined in the Demerara Plateau but not have enough elements are available at the moment to apply the same model.

Nonetheless, this issue demonstrates the limit of using carbonates for radiocarbon dating in highly dynamic settings or in environments possibly affected by fluids circulation, which might control the geochemical features of biogenic carbonates. This topic remains "open" in this work. Ideally, a more accurate dating method is required to verify the chronological framework of the sediment successions in this very peculiar area. 


\subsection{Formation of the "giant flute casts"}

As stated before, hundreds of depressions resembling giant flute casts shape the seafloor on the DP. They are all elongated in a NW-SE direction concordantly with the direction of the current measured by mooring equipment (Fig. 11). These depressions are located above outcropping MTDs or sedimentary highs (Fig. 4), where the recent sediment cover is thin (<10 m, Fig. 7).

These depressions were previously interpreted as pockmarks elongated by currents, but no geochemical anomalies could be observed on cores collected within them (Loncke et al., in press).

On the basis of these new data, these elongated depressions, described as "giant flute casts", can be interpreted as comet-tails (Werner et al., 1980; Stow et al., 2009) reflecting erosional features generated by the current flow around obstacles (outcropping MTDs or sedimentary highs) on the seafloor. The recorded bottom current values $(30 \mathrm{~cm} / \mathrm{s})$ are consistent with the development of such erosional longitudinal features (Werner et al., 1980; Stow et al., 2009).

Nonetheless, some of these depressions could be regarded as fossil pockmarks elongated by deep currents, as observed on the Norwegian margin (Bøe et al., 1998).

\subsection{Contourite drifts and contourite moats}

Recent sedimentation (post LM/EP MTD) is characterized by variable unit thicknesses on the DP (Fig. 7). Between $1800 \mathrm{~m}$ and $2400 \mathrm{~m}$ depth, the isopach map (Fig. 7) shows a NWSE depleted sedimentary belt, parallel to the main slope failure headscarp. This belt could be interpreted as a large contourite moat formed by a bottom current flow characterized by a high hydrodynamic regime, following the main slope failure headscarp which is itself clearly incised (Fig. 7 \& 8). Between $2400 \mathrm{~m}$ and $3500 \mathrm{~m}$, the sedimentation accumulation is thicker 
and forms a NW-SE oriented belt that thickens drastically (18 to $35 \mathrm{~m}$ of sediment) towards the southern divergent border of the plateau. Here, the current velocity probably decreases allowing suspended materials to deposite. This zone may correspond to the establishment of a large separated contourite drift on the DP. From $3500 \mathrm{~m}$ to $4500 \mathrm{~m}$ of depth, in the distal DP, sediment accumulation is very thin. Two hypotheses are possible to explain this phenomenon: (1) current speed might suddenly increase at the bottom along the slope failure inducing the formation of a confined moat; (2) the sediment load is too low to form an appreciable and extended sedimentary unit.

A NW-SE contourite moat follows the slope failure headscarp but some patchy sedimentary accumulations are nevertheless observed downslope of the failure headscarp (Fig. 7 and 8). They are elongated in the direction of the bottom current flow. The internal geometry of these accumulations shows downlapping clinoforms that are sometimes intercalated with small recent MTDs (Fig. 9). Some of those accumulations clearly initiate along recent slope failure headscarps and are interpreted as contourite infill drifts (Fig. 9.B) (Faugères et al., 1999; Rebesco and Stow, 2001; Rebesco, 2005; Rebesco et al., 2014). Others preferentially locate downslope of residual positive reliefs not destabilized by the most recent MTDs (Fig. 9C). These small patchy accumulations are plastered downslope of those reliefs (Fig. 9.C). This type of deposit is interpreted as patch drifts (Faugères et al., 1999; Rebesco and Stow, 2001; Rebesco, 2005; Hernández-Molina et al., 2006; Rebesco et al., 2014).

\subsection{Facies and sedimentary environment}

The previously defined facies can be linked to environmental conditions in terms of relative hydrodynamic regime variations and relative sedimentation rate variations (Table 3 and Fig. 13): 
- F1, in the Glauconite facies: the low $\mathrm{N}_{\mathrm{t}}$ content is supposedly related to the degradation and oxidation of organic matter, as expected in an environment associated with a high hydrodynamic regime and low sedimentation rate (Baudin et al., 2007).

- F2, Foraminifera sandy faciesreflects a relatively high hydrodynamic regime, similar to F1. The organic matter is degraded with low $\mathrm{N}_{t}$ and $\mathrm{C}_{\text {org }}$ content (Baudin et al., 2007), thus the winnowing effect is certainly high.

- F3, Foraminifera-bearing mud facies: the higher value of $\mathrm{N}_{t}$ and $\mathrm{C}_{\text {org }}$ might be related either to a period with high planktonic production or to a better preservation of the organic matter because of rapid burial (Baudin et al., 2007). It characterizes an environment with a low hydrodynamic regime.

- F4, Muddy facies: corresponds to a lower hydrodynamic regime. At the same time, the higher $\mathrm{N}_{\mathrm{t}}$ and $\mathrm{C}_{\text {org }}$ contents are related to good preservation of the organic matter preferentially linked to clay minerals (Baudin et al., 2007).

Variations of texture, sediment facies and grain size allow us to define some graded bedding with coarsening and fining upward sequences (Fig. 13) as typical contourites (Gonthier et al., 1984; Stow and Faugères, 2008). Negative grading is linked to increasing bottom current velocity and positively grading to decreasing velocity, as defined by Gonthier et al. (1984) and Stow et al. (2002a). Facies F1 is related to active hydrodynamic conditions characterized by winnowing and the bottom transport of sandy grains and is part of a contourite. On the other hand, facies F2 and F3 are not "pure" contourites, but might correspond to the transition between contourite sedimentation and hemipelagic conditions (Stow and Faugères, 2008), if the relatively high content in planktonic non-reworked foraminifera and also the rather good preservation of organic matter, indicating rapid sediment burial and/or less oxygenated bottom waters are considered (Baudin et al., 2007). F4 
is a clear hemipelagic facies, characterized by fine sedimentation, good preservation of the organic matter, and thus low regime hydrodynamic conditions.

\subsection{Wave fields}

One of the main features described on the DP are the NW-SE waves located above the MTDs. These longitudinal bedforms with a NW-SE elongated axis are very similar to sediment waves described throughout various continental margins (Lee et al., 2002). By definition, the crest of the sediment wave must be perpendicular or oblique to the current direction and migrate upslope (Wynn and Stow, 2002; Rebesco and Camerlenghi, 2008), but on the DP the crests of these features are parallel to the main current direction.

These structures are linear bedforms generated as longitudinal (triangular) waves (Flood, 1981, 1983; Blumsack and Weatherly, 1989; Tallobre et al., 2014) and they appear on a larger scale than expected in contourite environments. Nevertheless, it seems reasonable to define them as "longitudinal waves". An observation that may explain their development could relate to the emplacement of these waves on top of MTDs that present undulated morphologies. Moreover, some reflectors inside the MTD are folded indicating syn-deposition deformation (Fig. $5 \& 6$ ). These undulation are classic on top of MTDs and may be interpreted as pressure ridges (Prior et al., 1984; Maltman, 1994). During a period with high bottom current activity, the undulations on the top of MTDs may favor channelization and a local increase in current velocity in the axis of the successive hollows. On the side and crest of ridges, the channelization effect and flow velocity may be lower, allowing sedimentation (Fig. 6.D). Channelization of the deep current can generate helicoidal flows promoting the preservation of these longitudinal structures (Flood, 1981, 1983). The waves, which are located in the area with the large drift (between 2400 and $3500 \mathrm{~m}$ of water depth), present a lower height and wavelength (in average $4.85 \mathrm{~m}$ of height and $856 \mathrm{~m}$ of wavelength on the Figure 6.A against 
$8.84 \mathrm{~m}$ of height and $875 \mathrm{~m}$ of wavelength). This might mean that sedimentation progressively infills the hollow of the waves and smoothes the seafloor (Fig. 6).

One of the characteristics of these bedforms is the upslope migration. Three factors may explain this migration. First, it is possible that the Coriolis force which deflects the flow to the right (northern hemisphere) and constrains the flow and sediment against the slope, and then generates an upslope migration of these structures (Faugères et al., 1999). Another hypothesis is the interaction with the semidiurnal tidal constituent which was recorded with the mooring (Fig. 12). Egbert and Ray (2000) showed that a strong M2 tidal energy dissipation is present even in the deep ocean and that the presence of significant bathymetric roughness has a significant role on this dissipation. In this study, a strong tidal energy dissipation was demonstrated along the deep Guiana and North Brazil margin which, associated with the rough DP topography, is consistent with our semidiurnal tidal signal. The interaction between bedform migrations, such as sediment waves, and tidal influence has been described in the Bay of Biscay (Faugères et al., 2002) or the Irish Sea (Van Landeghem et al., 2012). Finally, the interaction between the topography and the main flow direction can generate a secondary flow that is oblique to the main direction, promoting upslope migration as described for transverse dunes by Walker and Shugar (2013).

\subsection{Comparison with other marginal plateaus}

One specificity of the study area lies in the presence of a marginal plateau. The depth and morphology of such plateau may be particularly favorable for guiding deep currents. As shown in literature with the example of the Mid Norwegian Margin (Berg et al., 2005; Bryn et al., 2005), the contouritic deposits induced by those currents may favor slope instability and thus explain the alternation of mass-wasting and contourite deposits on the DP. In our case, the dating of the described contouritic sequences will be a key to better constrain those interactions. 
Some similar configurations to the DP, with a marginal plateau associated to CDS, are also described in the literature. For example in the Argentine basin along the Falkland plateau, an impressive mud wave field, moat and contouritic channels were identified in HernándezMolina et al. (2009) and Hernández-Molina et al. (2010). The deep currents are constrained around the Falkland plateau and a CDS is formed along its lower slope (Hernández-Molina et al., 2010). On the Guinea marginal plateau, the NADW flow induces the formation of sediment wave fields on the seafloor (Rossi et al., 1992; Westall et al., 1993) which can be a component of a CDS. In sedimentary recording, CDS establishments on a marginal plateau are also described the Ivory Coast Rise for the Eocene epoch (Jones and Okada, 2006) and more recently for the Pleistocene (Giresse, 2008). Another example is the Mid Norwegian Margin. In this area, during the period from the Late Eocene to Mid Pliocene, the deep currents were constrained and turned around the sub-marine bathymetric relief formed by the Vøring marginal plateau (Laberg et al., 2005; Hernández-Molina et al., 2008a). Since the Late Pliocene, the main flow and the main contourite deposit cross straight through the Vøring Plateau, and only secondary flow occur with low sedimentary deposits occur on the plateau slope (Orvik and Niiler, 2002; Bryn et al., 2005; Laberg et al., 2005; Hernández-Molina et al., 2008a).

The fact that CDS are often associated to marginal plateaus is consistent with literature: indeed CDS are commonly described in association with bathymetric highs as seamount chains, plateaus, banks, ridges (Hernández-Molina et al., 2008b). In this context, CDS are characterized by the presence of erosional features (contourite channels, scours marks), as found on the DP, generated by the interaction between the impinging water mass and the bathymetry high (Hernández-Molina et al., 2008b). This may support that such along slope processes are particularly active in such settings where the topography constrains deep current flows. 


\section{Conclusions}

The main results can be resumed in two major points: (1) a Contourite Depositional System (CDS) is present on the DP, and (2) the formation and the evolution of singular longitudinal waves seem to be associated to this CDS.

(1) The NADW bottom current generated a CDS on the DP. Bathymetric and seismic data highlight the complexity of the sedimentary bodies, the presence of incisions and moats along the main regional slope failure headscarp, elongated drifts, infill drifts, patch drifts, and erosional bedforms parallel to the current (comet-tails). The core data allowed us to detail the characteristics of the sediment, where fining and coarsening upward sequences are recognized which can correspond to the standard contourite sequence defined by (Gonthier et al. (1984)) and Stow and Faugères (2008). Furthermore, variations in organic matter testify to the alternation of periods of winnowing and deposition. The complex CDS geometry is related to the slope instability processes that strongly control the paleotopography and interfere locally with the main flow of the NADW. In particular, the NADW bottom current seems to be guided by the main slope failure headscarp which is expressed by numerous linear erosional features (elongated moat, hundreds of nearby comet tails). The observed comet-tails all develop where MTDs or sedimentary highs outcrop on the seafloor, where blocks probably forming obstacles for the current and longitudinal waves seem to develop above an irregular MTD top. Further studies are needed to establish a solid chronological framework and to link the variations in hydrodynamic regime to the global climate.

(2) On the DP, a particular type of bedform, i.e. longitudinal waves are described; they are similar to sediment waves on bathymetry and seismic data. The main difference between these newly identified structures and sediment waves explains their orientation: in this area they are elongated parallel to the main flow direction. The formation of the longitudinal 
waves on the DP appears to be in relation with the paleo-bathymetry and these bedforms probably have an inherited origin initiating on seafloor undulations caused by an older MTD.

Finally, it is worth to notice that the shape of the Demerara plateau and its position, far from continental terrigenous inputs, are suspected to promote the expression of along-slope sedimentary processes as contourites. It is the case in many others marginal plateaus (the Falkland Plateau, the Guinea Plateau, the Vøring Plateau, the Ivory Coast rise) where wellexpressed CDS were identified. They are probably preferential areas to form and preserve CDS. Finally, it is likely that marginal plateaus form bathymetric highs that interact with impinging water masses and allow the development of CDS' characterized by widespread linear erosion features (Hernández-Molina et al., 2008b).

Future work in this area should aim at better understanding the formation and evolution of the longitudinal waves, and better constraining the interactions between contourites, sediment supply, current variations, climate variations, structure of the margin and slope instabilities.

\section{Acknowledgements}

The authors would like to thank the crew of the N/O Atalante. We also thank Shell for supporting Cédric Tallobre's PhD Project, IFREMER for technical support, Angélique Roubi and Mikael Rovere, the CEFREM, Christophe Menniti and Stéphane Kunesch for access to laboratory facilities and assistance. Many thanks to the graduate students who worked on this topic: Mirjam Randla, Lea Bonnin and Simon Faye. Finally, authors thank reviewers and editors for their contributions to improve this paper.

*IGUANES Scientific Party: C. Basile, S. Bermell, H. Berrenstein, C. Cathalot, J.C. Caprais, L. Droz, D. Graindorge, B. Hebert, A. Heuret, J.F. Lebrun, A. Maillard, T. Marsset, M. Mercier de Lépinay, F. Pattier, E. Poetisi, W.R. Roest, C. Sotin, B.C. Vendeville. 


\section{Figure captions}

Figure 1: General map of the study area (from Google Earth).

Figure 2: Bathymetry of the Demerara Plateau and positions of regional ocean currents in the western part of the equatorial Atlantic Ocean and their physico-chemical properties. The bathymetric data are derived from the IGUANES and GUYAPLAC cruises.

Figure 3: Bathymetry of the Demerara Plateau, with locations of all sediment cores collected during the IGUANES cruise and the mooring site. The seismic lines, chirp profiles and figures used in this paper are also shown. The extension of the Last Miocene /Early Pliocene MTD (in gray) and post-LM/EP MTDs (in purple) is reported for the study area. The crests of the sedimentary waves are plotted on this map (blue line).

Figure 4: Position and regional context of core IG-KSF-11 (0751.085'N; 52²9.025' W). A. Bathymetry map with waves and comet-tail features. B. High Resolution profile IG-053 and C. Chirp profile IG-053. IG-KSF-11 was collected in bedded sediment upstream of the depression in relation to the current direction (NW-SE) above a sedimentary high. The core reaches the yellow horizon plotted on the chirp.

Figure 5: Characteristics of sedimentary waves on the seafloor and seismic lines A. Bathymetry illustrating the bedforms on the seafloor elongated along a NW-SE axis, B. HR seismic profile IG-031 C. Chirp profile IG-031: Transverse view of the waves. 3 MTDs (in yellow, orange for pre-Miocene MTDs and gray for the LM/EP MTD) cut the stratigraphy with an erosive base. In gray, the LM/EP MTD with an undulated top which initiates the waves. D. Isopach band calculated along profile IG-031 between the seafloor and the yellow horizon. The letters correspond to the crest of waves on the Chirp, illustrating the thinnest deposit on the side of wave and the thickest deposit on the crest. 
Figure 6: Characteristics of sedimentary waves in the area where they appear smoother $\mathbf{A}$. High resolution seismic profile IG-043, waves with low amplitude above the LM/EP MTD with high post-MTD sedimentation rates which smooth the waves on the seafloor. B. High Resolution seismic profile IG-034, with post-LM/EP MTD (in purple). Post-LM/EP MTDs cover the undulated top of LM/EP MTD and prevent the formation of waves.

Figure 7: Isopach map in meters (considering a mean overburden seismic velocity of 1.5 $\mathrm{km} / \mathrm{s}$ ) of sedimentary deposits calculated between the seafloor and the yellow horizon (see Figures $6 \& 8$ ). The different HR seismic lines, chirp profiles and core IG-KSF-11 are positioned on this map.

Figure 8: Chirp profile IG-130 crossing the slope failure headscarp, showing the patchy accumulation and moat. This profile illustrates the sedimentary accumulation against the slope failure headscarp and the patchy deposit that have been evidenced in the isopach map (Figure 7).

Figure 9: Detail of different sedimentary accumulations on the DP: onlapping and patchy accumulations. A. Bathymetric map illustrating the position of the slope failure headscarp with a concave shape, the position of the MTD alignment of pockmarks, sedimentary accumulations and moats. B. Illustration of an onlapping accumulation in the topographic depression of the slope failure headscarp interpreted as an infill drift and moat. C. Illustration of patchy accumulations plastered on the edge of topographic reliefs on the seafloor, interpreted as patch drifts.

Figure 10: Time series of near-bottom hydrodynamic and hydrological parameters recorded between May 2013 and March 2014 at the mooring site $\left(08^{\circ} 01.080^{\prime} \mathrm{N}, 52^{\circ} 21.331^{\prime}\right.$ W). A. Stick plot of current B. Current speed $\left(\mathrm{cm} \mathrm{s}^{-1}\right)$ C. Potential temperature $\left({ }^{\circ} \mathrm{C}\right)$ and Salinity (\%o) and D. Turbidity (NTU). 
Figure 11: Scatter plot of currents (black dots), major and minor axes of the current ellipse (black lines) and mean flow (red vector) recorded between May 2013 and March 2014 at the mooring site $\left(08^{\circ} 01.080^{\prime} \mathrm{N}, 52^{\circ} 21.331^{\prime} \mathrm{W}\right)$. The major axis of the ellipse lies along the direction of maximum current variance and the minor axis is normal to it. The direction of the local sediment wave is indicated by the blue line.

Figure 12: Variance preserving spectra of along-slope and cross-slope near-bottom current components at the mooring site $\left(08^{\circ} 01.080^{\prime} \mathrm{N}, 52^{\circ} 21.331^{\prime} \mathrm{W}\right)$, evidencing the predominance of the semidiurnal tidal constituent (M2 principal lunar). Current components are rotated by $124^{\circ}$ to lie along the major and minor axes of the current ellipse.

Figure 13: Sedimentary log of core IG-KSF-11, including core photos, lithology, facies (cf Table 3), estimation of the hydrodynamic regime, $\mathrm{Ca} / \mathrm{Fe}, \mathrm{Ti} / \mathrm{Ca}$ and $\mathrm{Si} / \mathrm{Ca}$ ratios, organic matter analyses with total nitrogen content $\mathrm{N}_{\mathrm{t}}(\%$ dry weight d.w.) and organic carbon content $\mathrm{C}_{\text {org }}(\%$ d.w.), sand content (\% d.w.), carbonate content $\%$ d.w.) and glauconite content in the sandy fraction (\% d.w. in $\log$ scale).

\section{References}

Aharon, P., Schwarcz, H.P., Roberts, H.H., 1997. Radiometric dating of submarine hydrocarbon seeps in the Gulf of Mexico. Geological Society of America Bulletin 109, 568579 .

Apel, J.R., 1988. Chapter Two Forcing Functions and Responses, in: John, R.A. (Ed.), International Geophysics. Academic Press, pp. 13-60.

Arz, H.W., Pätzold, J., Wefer, G., 1998. Correlated Millennial-Scale Changes in Surface Hydrography and Terrigenous Sediment Yield Inferred from Last-Glacial Marine Deposits off Northeastern Brazil. Quaternary Research 50, 157-166.

Basile, C., Maillard, A., Patriat, M., Gaullier, V., Loncke, L., Roest, W., Mercier de Lépinay, M., Pattier, F., 2013. Structure and evolution of the Demerara Plateau, offshore French Guiana: Rifting, tectonic inversion and post-rift tilting at transform-divergent margins intersection. Tectonophysics 591, 16-29.

Baudin, F., Tribovillard, N., Trichet, J., 2007. Géologie de la matière organique, Coédition avec la société géologique de France ed.

Benkhelil, J., Mascle, J., Tricart, P., 1995. The Guinea continental margin: an example of a structurally complex transform margin. Tectonophysics 248, 117-137.

Berg, K., Solheim, A., Bryn, P., 2005. The Pleistocene to recent geological development of the Ormen Lange area. Marine and Petroleum Geology 22, 45-56. 
Blumsack, S.L., Weatherly, G.L., 1989. Observations of the nearby flow and a model for the growth of mudwaves. Deep Sea Research Part A. Oceanographic Research Papers 36, 13271339.

Bøe, R., Rise, L., Ottesen, D., 1998. Elongate depressions on the southern slope of the Norwegian Trench (Skagerrak): morphology and evolution. Marine Geology 146, 191-203.

Bordovskiy, O.K., 1965a. Accumulation of organic matter in bottom sediments. Marine Geology 3, 33-82.

Bordovskiy, O.K., 1965b. Sources of organic matter in marine basins. Marine Geology 3, 531.

Bordovskiy, O.K., 1965c. Transformation of organic matter in bottom sediments and its early diagenesis. Marine Geology 3, 83-114.

Bryn, P., Berg, K., Stoker, M.S., Haflidason, H., Solheim, A., 2005. Contourites and their relevance for mass wasting along the Mid-Norwegian Margin. Marine and Petroleum Geology 22, 85-96.

Cauwet, G., Gadel, F., de Souza Sierra, M.M., Donard, O., Ewald, M., 1990. Contribution of the Rhône River to organic carbon inputs to the northwestern Mediterranean Sea. Continental Shelf Research 10, 1025-1037.

Damuth, J.E., Kumar, N., 1975. Late Quaternary depositional processes on the continental rise of the western Equatorial Atlantic: comparison with the western north Atlantic and implication for reservoir-rock distribution. . AAPG Bulletin 59, 2172-2181.

Egbert, G.D., Ray, R.D., 2000. Significant dissipation of tidal energy in the deep ocean inferred from satellite altimeter data. Nature 405, 775-778.

Erbacher, J., Mosher, D.C., Malone, M.J., et al., 2004. in: Proceedings of the Ocean Drilling Program, I.R. (Ed.).

Faugères, J.-C., Gonthier, E., Mulder, T., Kenyon, N., Cirac, P., Griboulard, R., Berné, S., Lesuavé, R., 2002. Multi-process generated sediment waves on the Landes Plateau (Bay of Biscay, North Atlantic). Marine Geology 182, 279-302.

Faugères, J.-C., Gonthier, E., Stow, D.A.V., 1984. Contourite drift molded by deep Mediterranean outflow. Geology 12, 296-300.

Faugères, J.-C., Stow, D.A.V., Imbert, P., Viana, A., 1999. Seismic features diagnostic of contourite drifts. Marine Geology 162, 1-38.

Faugères, J.C., Mézerais, M.L., Stow, D.A.V., 1993. Contourite drift types and their distribution in the North and South Atlantic Ocean basins. Sedimentary Geology 82, 189-203.

Flood, R.D., 1981. Distribution, morphology, and origin of sedimentary furrows in cohesive sediments, Southampton Water. Sedimentology 28, 511-529.

FLOOD, R.D., 1983. Classification of sedimentary furrows and a model for furrow initiation and evolution. Geological Society of America Bulletin 94, 630-639.

Gardner, W.D., Southard, J.B., Hollister, C.D., 1985. Sedimentation, resuspension and chemistry of particles in the northwest Atlantic. Marine Geology 65, 199-242.

Garfield, I.N., 1990. The Brazil Current at subtropical latitudes. university of Rhode Island, p. 122.

Gibbs, R.J., 1980. Wind-controlled coastal upwelling in the western equatorial Atlantic. Deep Sea Research Part A. Oceanographic Research Papers 27, 857-866.

Giresse, P., 2008. Chapter 12 Some Aspects of Diagenesis in Contourites, in: Rebesco, M., Camerlenghi, A. (Eds.), Developments in Sedimentology. Elsevier, pp. 203-221.

Gonthier, E., Faugères, J.C., Stow, D.A.V., 1984. Contourite facies of the Faro drift. Geological society of London, special publication 15, 275-292.

Gouyet, S., 1988. Evolution tectono-sédimentaire des marges guyanaise et nordbrésilienne au cours de l'ouverture de l'Atlantique Sud. Université de Pau, p. 374. 
Hanebuth, T.J.J., Zhang, W., Hofmann, A.L., Löwemark, L.A., Schwenk, T., 2015. Oceanic density fronts steering bottom-current induced sedimentation deduced from a $50 \mathrm{ka}$ contourite-drift record and numerical modeling (off NW Spain). Quaternary Science Reviews 112, 207-225.

Heezen, B.C., Hollister, C., 1964. Deep-sea current evidence from abyssal sediments. Marine Geology 1, 141-174.

Hernández-Molina, F.J., Larter, R.D., Rebesco, M., Maldonado, A., 2006. Miocene reversal of bottom water flow along the Pacific Margin of the Antarctic Peninsula: Stratigraphic evidence from a contourite sedimentary tail. Marine Geology 228, 93-116.

Hernández-Molina, F.J., Llave, E., Stow, D.A.V., 2008a. Chapter 19 Continental Slope Contourites, in: Rebesco, M., Camerlenghi, A. (Eds.), Developments in Sedimentology. Elsevier, pp. 379-408.

Hernández-Molina, F.J., Maldonado, A., Stow, D.A.V., 2008b. Chapter 18 Abyssal Plain Contourites, in: Rebesco, M., Camerlenghi, A. (Eds.), Developments in Sedimentology. Elsevier, pp. 345-378.

Hernández-Molina, F.J., Paterlini, M., Somoza, L., Violante, R., Arecco, M.A., de Isasi, M., Rebesco, M., Uenzelmann-Neben, G., Neben, S., Marshall, P., 2010. Giant mounded drifts in the Argentine Continental Margin: Origins, and global implications for the history of thermohaline circulation. Marine and Petroleum Geology 27, 1508-1530.

Hernández-Molina, F.J., Paterlini, M., Violante, R., Marshall, P., de Isasi, M., Somoza, L., Rebesco, M., 2009. Contourite depositional system on the Argentine Slope: An exceptional record of the influence of Antarctic water masses. Geology 37, 507-510.

Hogg, N.G., 1997. The Deep Basin Experiment - status and accomplishments. , WOCE South Atlantic Workshop, Brest.

Hogg, N.G., Brechner Owens, W., 1999. Direct measurement of the deep circulation within the Brazil Basin. Deep Sea Research Part II: Topical Studies in Oceanography 46, 335-353.

Hollister, C.D., 1967. Sediment distribution and deep circulation in the western North Atlantic. Columbia University, New York, p. 467.

Howe, J.A., Pudsey, C.J., 1999. Antarctic Circumpolar Deep Water; a Quaternary paleoflow record from the northern Scotia Sea, South Atlantic Ocean. Journal of Sedimentary Research 69, 847-861.

Ingram, W.C., Mosher, D.C., Wise, S.W.J., 2011. Biostratigraphy of an upper Miocene masstransport deposit on Demerara Rise, northern South American margin, in: Shipp, C., Weimer, P., Posamentier, H. (Eds.), Mass-transport Deposits in Deepwater Settings. SEPM Special Publication 96, pp. 457-498.

Jansen, J.H.F., Van der Gaast, S.J., Koster, B., Vaars, A.J., 1998. CORTEX, a shipboard XRF-scanner for element analyses in split sediment cores. Marine Geology 151, 143-153.

Johns, W.E., Fratantoni, D.M., Zantopp, R.J., 1993. Deep western boundary current variability off northeastern Brazil. Deep Sea Research Part I: Oceanographic Research Papers 40, 293-310.

Jones, E.J.W., Okada, H., 2006. Abyssal circulation change in the equatorial Atlantic: Evidence from Cenozoic sedimentary drifts off West Africa. Marine Geology 232, 49-61.

Klitgord, K.D., Schouten, H., 1986. Plate kinematics of the central Atlantic., in: Vogt, P.R., Tucholke, B.E. (Ed.), The Western North Atlantic Region. Geological Society of America, Boulder, pp. 351-378.

Laberg, J.S., Dahlgren, K.I.T., Vorren, T.O., 2005. The Eocene-late Pliocene paleoenvironment in the Vøring Plateau area, Norwegian Sea-paleoceanographic implications. Marine Geology 214, 269-285. 
Lee, H.J., Syvitski, J.P.M., Parker, G., Orange, D., Locat, J., Hutton, E.W.H., Imran, J., 2002. Distinguishing sediment waves from slope failure deposits: field examples, including the 'Humboldt slide', and modelling results. Marine Geology 192, 79-104.

Loncke, L., Droz, L., Gaullier, V., Basile, C., Patriat, M., Roest, W., 2009. Slope instabilities from echo-character mapping along the French Guiana transform margin and Demerara abyssal plain. Marine and Petroleum Geology 26, 711-723.

Loncke, L., Maillard, A., Basile, C., Roest, W., Bayon, G., Pattier, F., Mercier de Lépinay, M., Grall, C., Droz, L., Marsset, T., Giresse, P., Caprais, J.C., Cathalot, C., Graindorge, D., Heuret, A., Lebrun, J.F., Bermell, S., Marcaillou, B., Bassetti, M.A., Tallobre, C., Buscail, R., Durrieu de Madron, X., Bourrin, F., in press. Structure of the Demerara passive transform margin and associated sedimentary processes. Preliminary results from the IGUANES cruise. Geological society of London, special publication In press.

Lynch-Stieglitz, J., Adkins, J.F., Curry, W.B., Dokken, T., Hall, I.R., Herguera, J.C., Hirschi, J.J.-M., Ivanova, E.V., Kissel, C., Marchal, O., Marchitto, T.M., McCave, I.N., McManus, J.F., Mulitza, S., Ninnemann, U., Peeters, F., Yu, E.-F., Zahn, R., 2007. Atlantic Meridional Overturning Circulation During the Last Glacial Maximum. Science 316, 66-69.

Maltman, A., 1994. The Geological Deformation of Sediments. Springer Netherlands.

Massé, L., Faugères, J.C., Hrovatin, V., 1998. The interplay between turbidity and contour current processes on the Columbia Channel fan drift, Southern Brazil Basin. Sedimentary Geology 115, 111-132.

Mauritzen, C., Polzin, K.L., McCartney, M.S., Millard, R.C., West-Mack, D.E., 2002. Evidence in hydrography and density fine structure for enhanced vertical mixing over the Mid-Atlantic Ridge in the western Atlantic. Journal of Geophysical Research: Oceans 107, 3147-3166.

McCave, I.N., 1986. Local and global aspects of the bottom nepheloid layers in the world ocean. Netherlands Journal of Sea Research 20, 167-181.

Molinari, R.J., Fine, R.A., E., J., 1992. The Deep Western Boundary Current in the tropical North Atlantic Ocean. Deep Sea Research 39, 1967-1984.

Monoley, C.L., Field, J.G., 1991. Modelling carbon and nitrogen flow in microbial plankton community., in: Reid, J.L.e.a. (Ed.), Protozoa and their role in marine processes. Springer, pp. 443-473.

Mosher, D.C., Erbacher, J., Malone, M., 2007. Leg 207 synthesis: extreme warmth, organicrich sediments, and an active deep biosphere: cretaceous-paleogene paleoceanographic depth transect at demerara rise, western tropical atlantic, in: Mosher, D.C., Erbacher, J., and Malone, M.J. (Ed.), Proceedings of the Ocean Drilling Program, Scientific Results.

Müller, P., 1977. CN ratios in Pacific deep-sea sediments:Effect of inorganic ammonium and organic nitrogen compounds sorbed by clays. Geochimica et Cosmochimica Acta 41, 765776.

Orvik, K.A., Niiler, P., 2002. Major pathways of Atlantic water in the northern North Atlantic and Nordic Seas toward Arctic. Geophysical Research Letters 29, 1896.

Pattier, F., 2013. Analyse et fonctionnement des sorties de fluide et glissements de la marge transformante Guyane-Surinam (plateau de Demerara). Couplages avec la structure de la marge. Université de Perpignan Via Domitia, p. 293.

Pattier, F., Loncke, L., Gaullier, V., Basile, C., Maillard, A., Imbert, P., Roest, W.R., Vendeville, B.C., Patriat, M., Loubrieu, B., 2013. Mass-transport deposits and fluid venting in a transform margin setting, the eastern Demerara Plateau (French Guiana). Marine and Petroleum Geology 46, 287-303.

Pattier, F., Loncke, L., Imbert, P., Gaullier, V., Basile, C., Maillard, A., Roest, W.R., Patriat, M., Vendeville, B.C., 2015. Origin of an enigmatic regional Mio-Pliocene unconformity on the Demerara plateau. Marine Geology 365, 21-35. 
Prior, D.B., Bornhold, B.D., Johns, M.W., 1984. Depositional Characteristics of a Submarine Debris Flow. The Journal of Geology 92, 707-727.

Rebesco, M., 2005. SEDIMENTARY ENVIRONMENTS | Contourites, in: Plimer, R.C.S.R.M.C.R. (Ed.), Encyclopedia of Geology. Elsevier, Oxford, pp. 513-527.

Rebesco, M., Camerlenghi, A., 2008. Contourites.

Rebesco, M., Hernández-Molina, F.J., Van Rooij, D., Wåhlin, A., 2014. Contourites and associated sediments controlled by deep-water circulation processes: State-of-the-art and future considerations. Marine Geology 352, 111-154.

Rebesco, M., Stow, D., 2001. Seismic expression of contourites and related deposits: a preface. Marine Geophysical Researches 22, 303-308.

Reid, J.L., 1989. On the total geostrophic circulation of the South Atlantic Ocean: Flow patterns, tracers, and transports. Progress in Oceanography 23, 149-244.

Reimer, P., Bard, E., Bayliss, A., Beck, J., Blackwell, P., Bronk Ramsey, C., Buck, C., Cheng, H., Edwards, R., Friedrich, M., Grootes, P., Guilderson, T., Haflidason, H., Hajdas, I., Hatté, C., Heaton, T., Hogg, A., Hughen, K., Kaiser, K., Kromer, B., Manning, S., Niu, M., Reimer, R., Richards, D., Scott, E., Southon, J., Turney, C., van der Plicht, J., 2013. IntCal13 and MARINE13 radiocarbon age calibration curves 0-50000 years calBP Radiocarbon 55(4).

Rossi, S., Westall, F., Mascle, J., 1992. The geomorphology of the Southwest Guinea Margin: tectonic, volcanic, mass movement and bottom current influences. Marine Geology 105, 225240.

Stow, D.A.V., Faugères, J.-C., Howe, J.A., Pudsey, C.J., Viana, A.R., 2002a. Bottom currents, contourites and deep-sea sediment drifts: current state-of-the-art. Bottom currents, contourites and deep-sea sediment drifts: current state-of-the-art. In: Stow, D.A.V., Pudsey, C.J., Howe, J.A., Faugères, J.-C., Viana, A.R. (Eds.), Deep-Water Contourite Systems: Modern Drifts and Ancient Series, Seismic and Sedimentary Characteristics: Geological Society London Memoir 22, 137-154.

Stow, D.A.V., Faugères, J.C., 2008. Chapter 13 Contourite Facies and the Facies Model, in: Rebesco, M., Camerlenghi, A. (Eds.), Developments in Sedimentology. Elsevier, pp. 223-256. Stow, D.A.V., Hernández-Molina, F.J., Llave, E., Sayago-Gil, M., Díaz del Río, V., Branson, A., 2009. Bedform-velocity matrix: The estimation of bottom current velocity from bedform observations. Geology 37, 327-330.

Stow, D.A.V., Kahler, G., Reeder, M., 2002b. Fossil contourites: type example from an Oligocene palaeoslope system, Cyprus. , in: Stow, D.A.V., Pudsey, C.J., Howe, J.A., Faugères, J.-C., Viana, A.R. (Eds.), Deep-water Contourite Systems: Modern Drifts and Ancient Series, Seismic and Sedimentary Characteristics., Geological Society, London, Memoir, pp. 443-455.

Survey, U., 2012. Atlantic meridional overturning circulation., in: Change, O.a.s.C.C. (Ed.). Talley, L.D., Pickard, G.L., Emery, W.J., Swift, J.H., 2011. Chapter 9 - Atlantic Ocean, in: Swift, L.D.T.L.P.J.E.H. (Ed.), Descriptive Physical Oceanography (Sixth Edition). Academic Press, Boston, pp. 245-301.

Tallobre, C., Giresse, P., Loncke, L., Bayon, G., Bassetti, M.A., Randla, M., Buscail, R., Durrieu de Madron, X., Bourrin, F., Kunesch, S., Sotin, C., Berné, S., Vanhaesebroucke, M., 2014. New findings of contourite-related structures and their implications on oceanographic and sedimentary conditions on the Demerara Plateau (French Guiana and Surinam), in: Rooij, D.V., Rüggeberg, A. (Eds.), 2nd Deep-Water Circulation Congress: "The Contourite Logbook", Ghent, Belgium.

Tsuchiya, M., Talley, L.D., McCartney, M.S., 1994. Water-mass distributions in the western South Atlantic; A section from South Georgia Island $\left(54^{\circ} \mathrm{S}\right)$ northward across the equator. Journal of Marine Research 52, 51-81. 
Unternehr, P., Curie, D., Olivet, J.L., Goslin, J., Beuzart, P., 1988. South Atlantic fits and intraplate boundaries in Africa and South America. Tectonophysics 155, 169-179.

Van Landeghem, K.J.J., Baas, J.H., Mitchell, N.C., Wilcockson, D., Wheeler, A.J., 2012. Reversed sediment wave migration in the Irish Sea, NW Europe: A reappraisal of the validity of geometry-based predictive modelling and assumptions. Marine Geology 295-298, 95-112.

Viana, A.R., 1998. Le rôle de l'enregistrement des courants océaniques dans les dépôts de marges continentales: la marge du Bassin Sud-Est brésilien. Univerisité de Bordeaux, p. 343.

Walker, I.J., Shugar, D.H., 2013. Secondary flow deflection in the lee of transverse dunes with implications for dune morphodynamics and migration. Earth Surface Processes and Landforms 38, 1642-1654.

Weatherly, G., Arhan, M., Mercier, H., Smethie Jr., W., 2002. Evidence of abyssal eddies in the Brazil Basin. Journal of Geophysical research 107.

Werner, F., Unsöld, G., Koopmann, B., Stefanon, A., 1980. Field observations and flume experiments on the nature of comet marks. Sedimentary Geology 26, 233-262.

Westall, F., Rossi, S., Mascle, J., 1993. Current-controlled sedimentation in the Equatorial Atlantic: examples from the southern margin of the Guinea Plateau and the Romanche Fracture Zone. Sedimentary Geology 82, 157-171.

Wynn, R.B., Stow, D.A.V., 2002. Classification and characterisation of deep-water sediment waves. Marine Geology 192, 7-22. 
ACCEPTED MANUSCRIPT

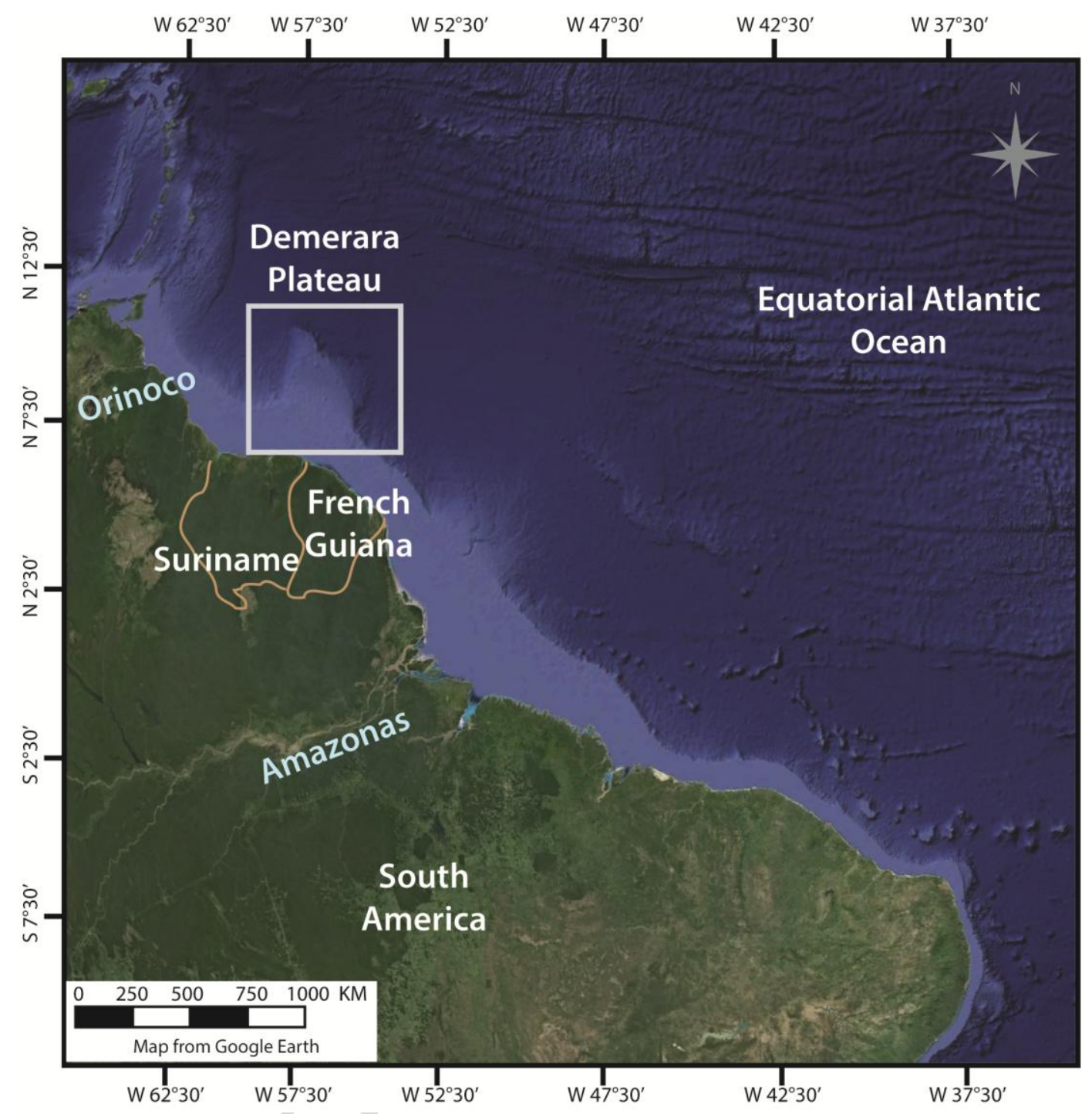

Fig. 1 


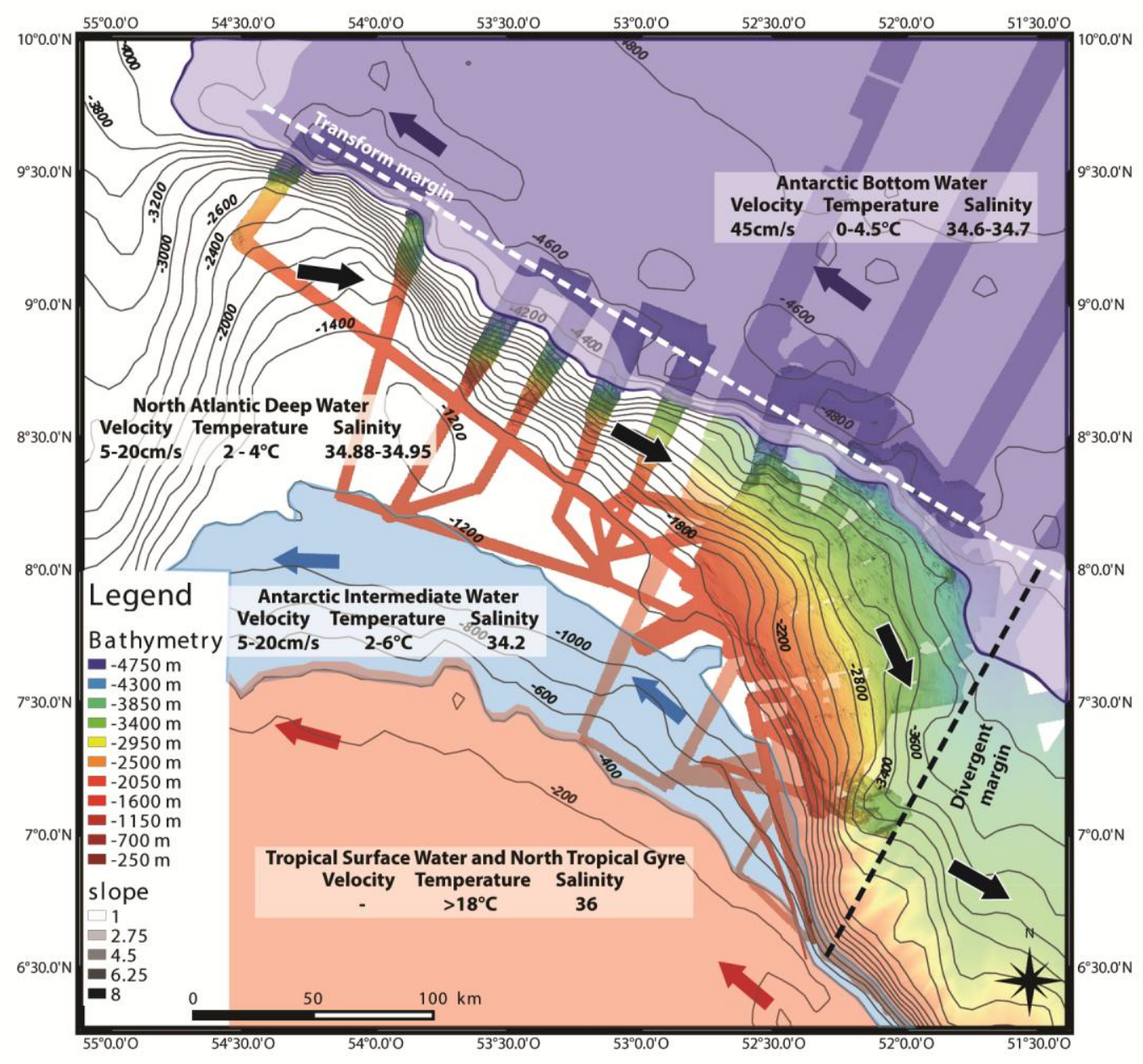

Fig. 2 


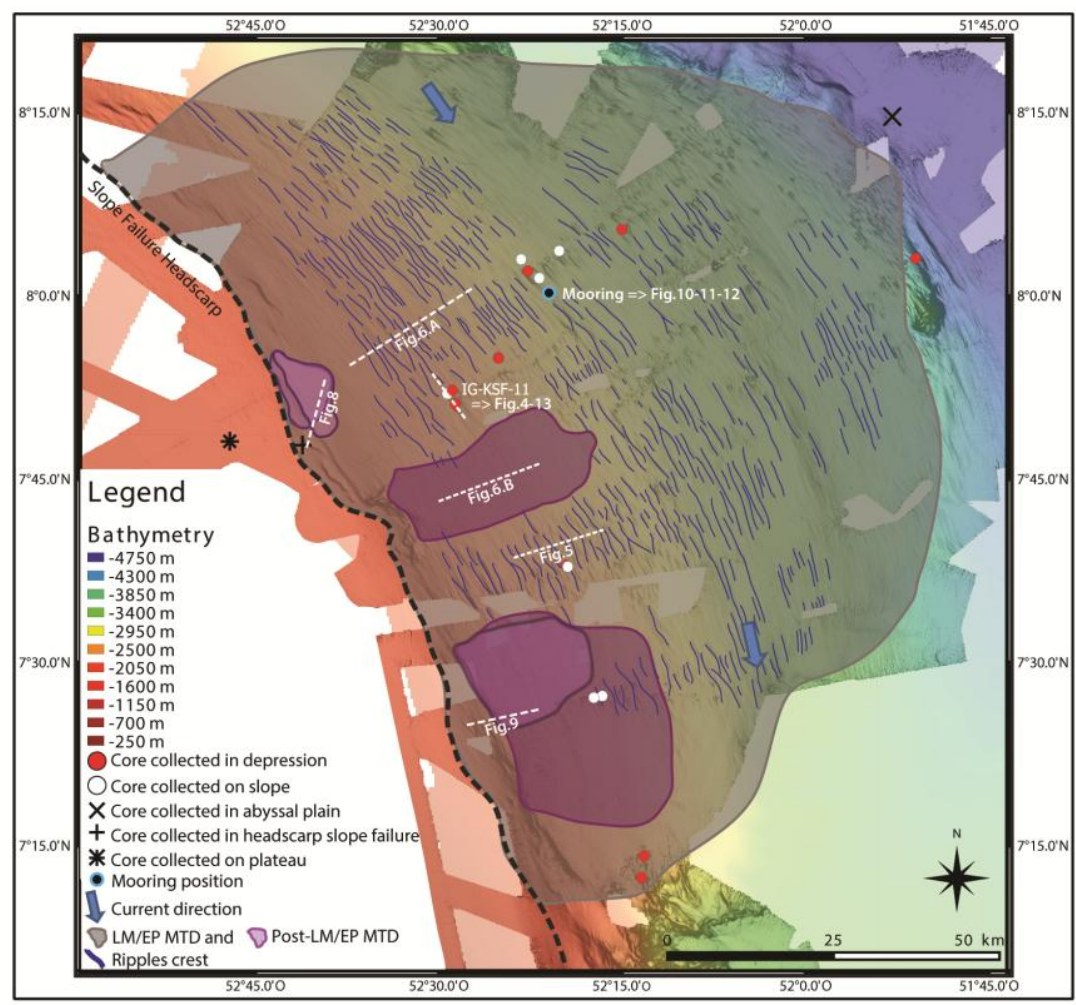

Fig. 3 


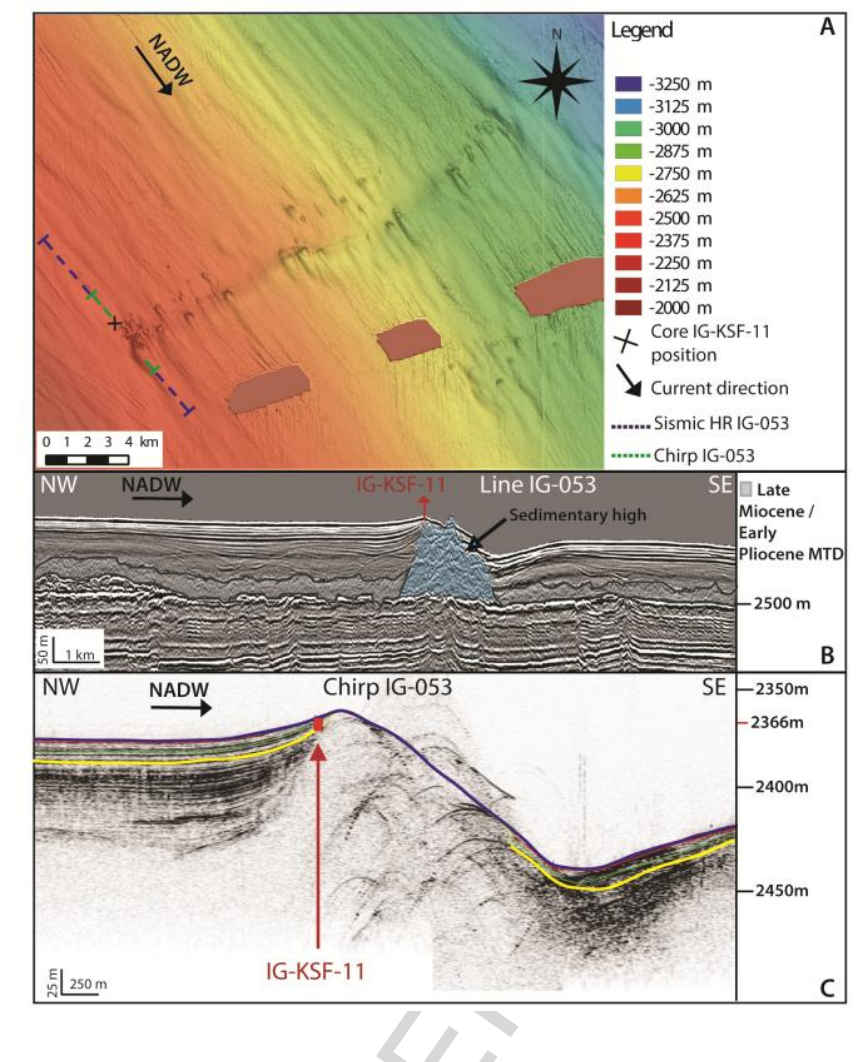

Fig. 4 


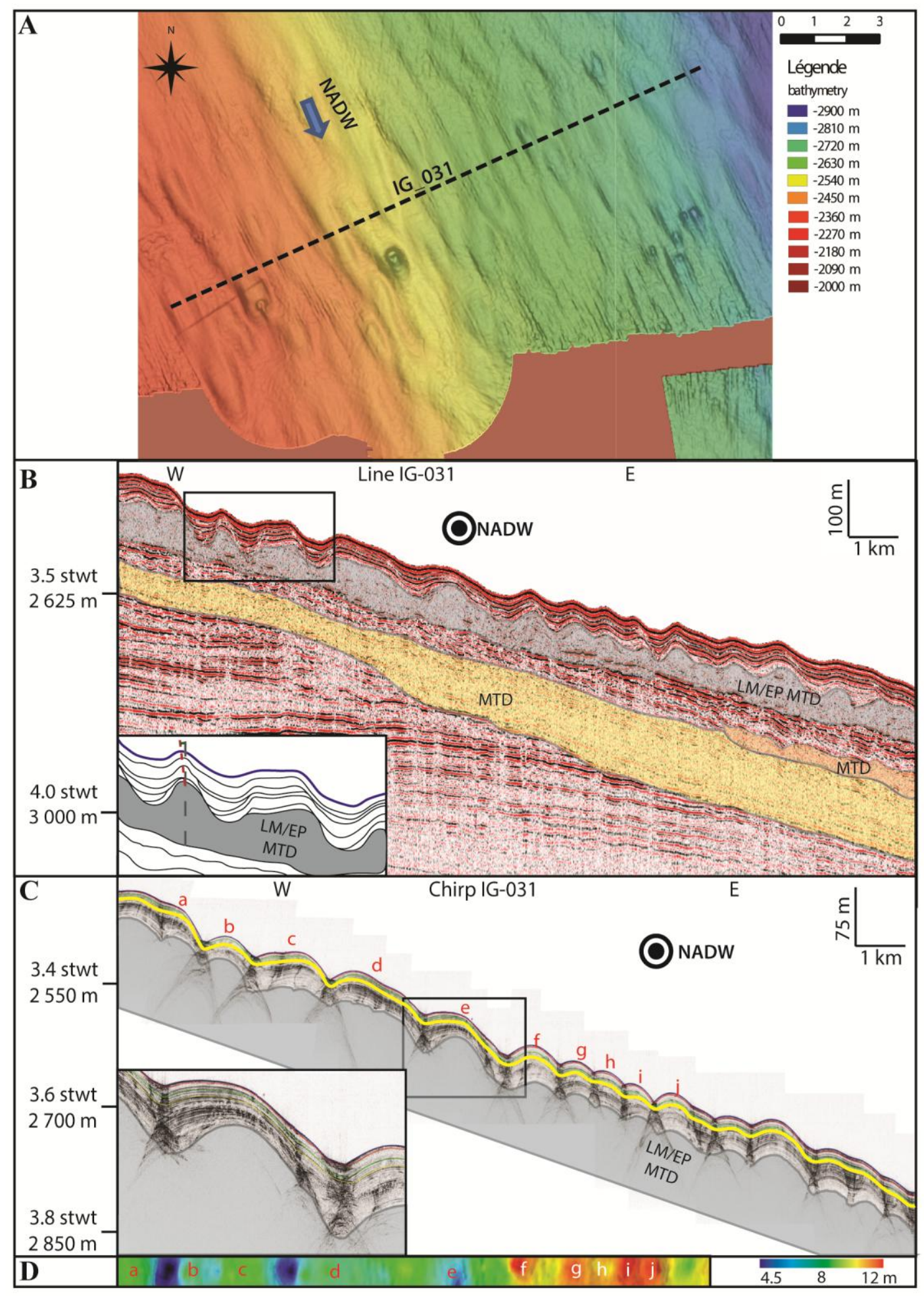

Fig. 5 


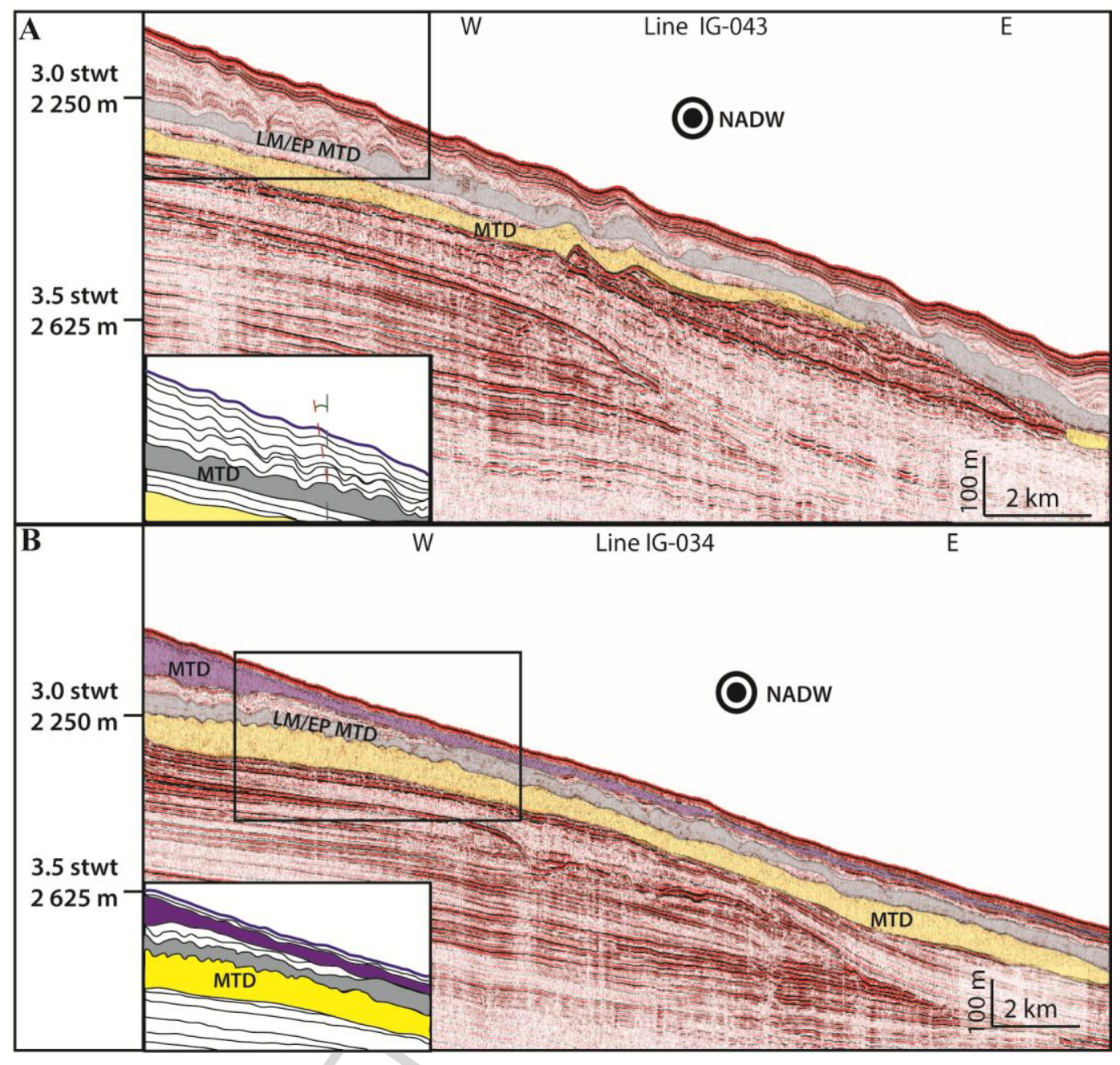

Fig. 6 


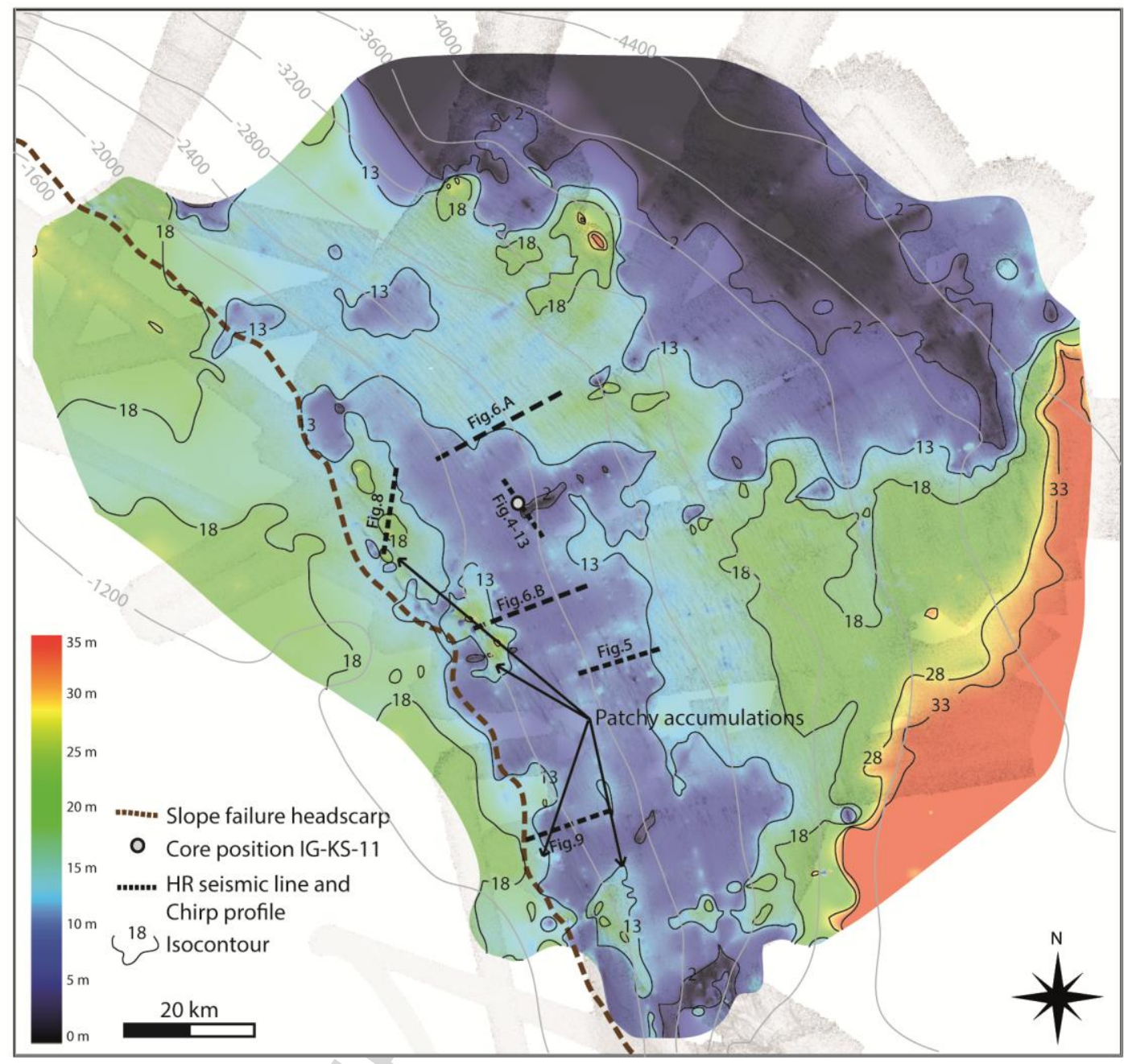

Fig. 7 


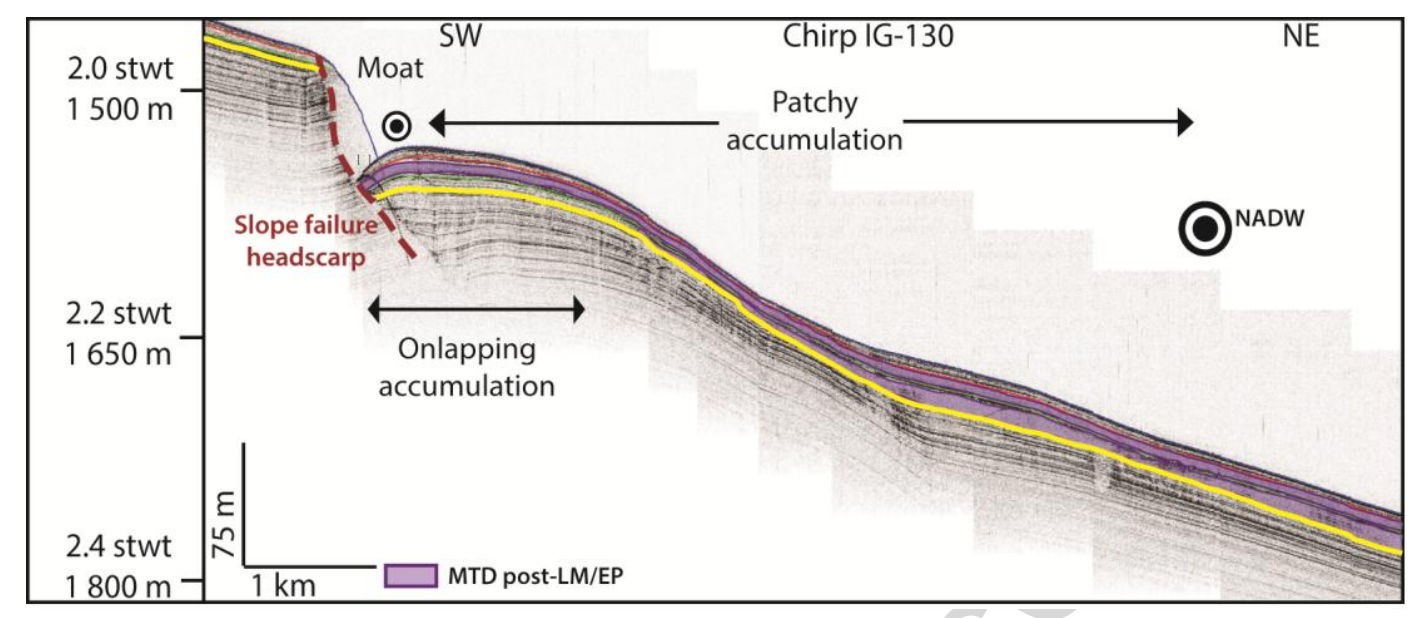

Fig. 8 


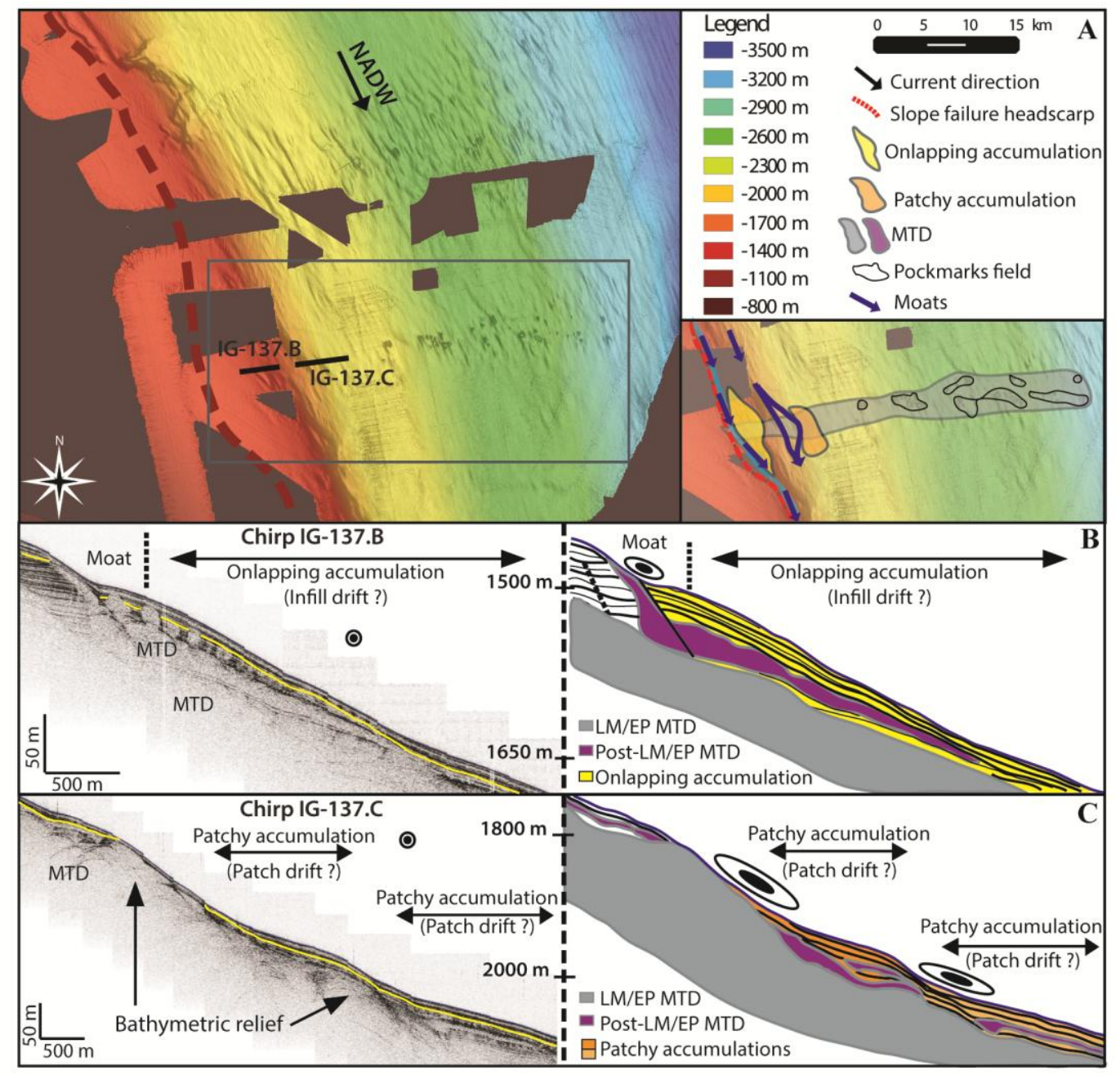

Fig. 9 

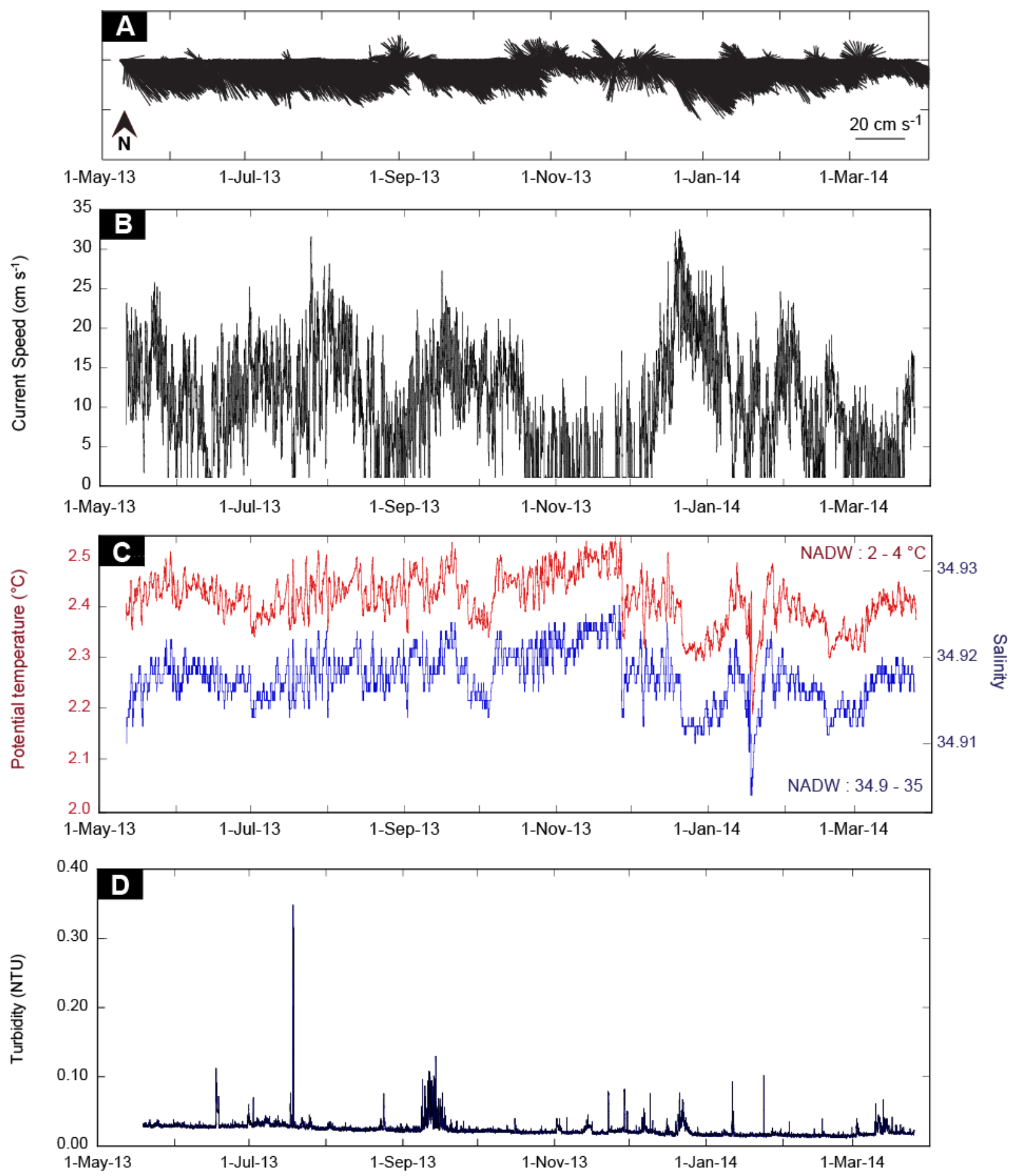

Fig. 10 


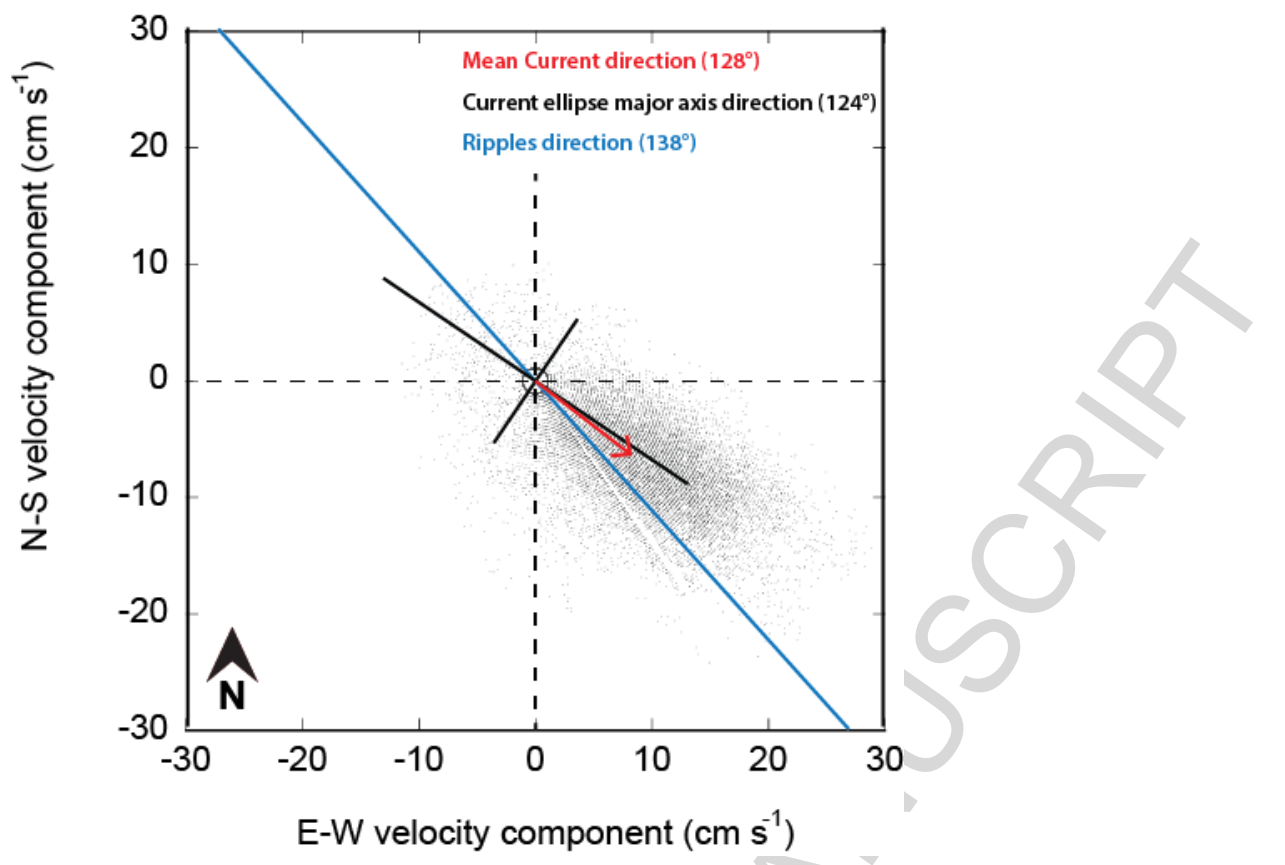

Fig. 11 

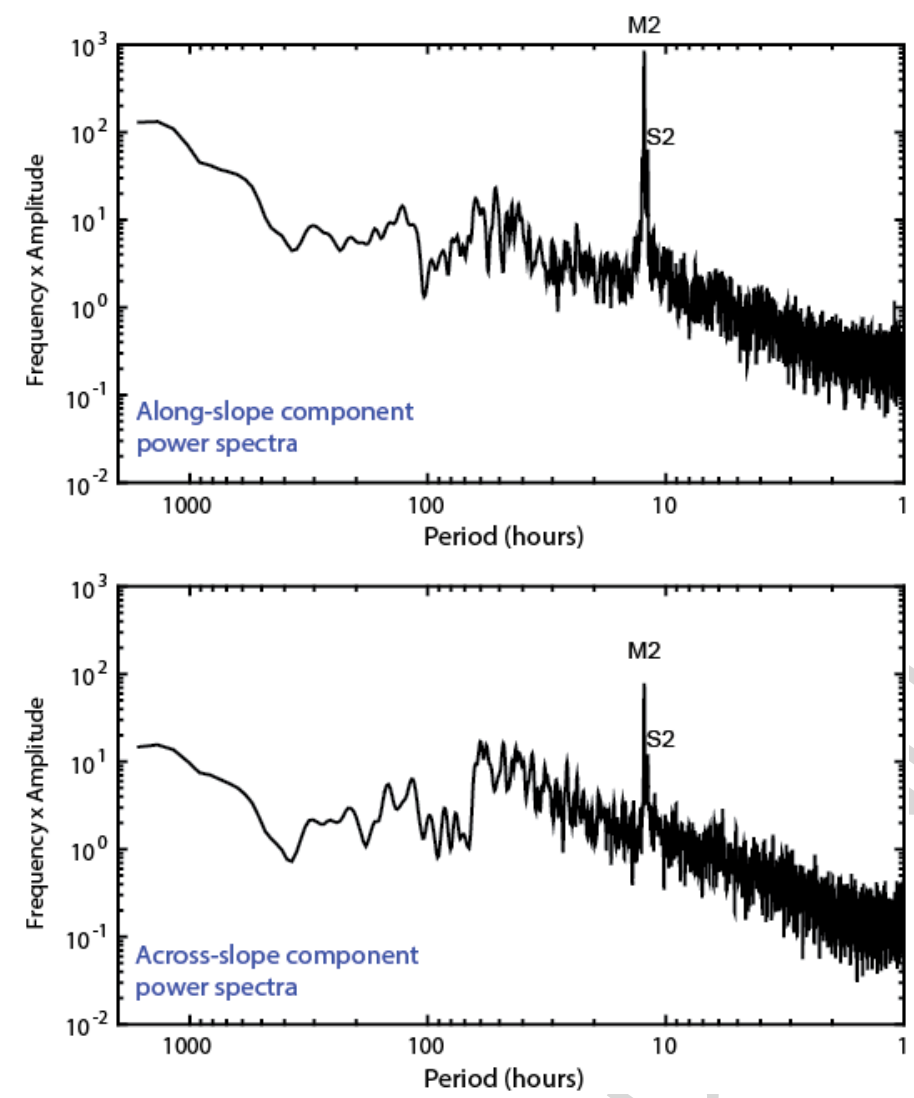

Fig. 12 


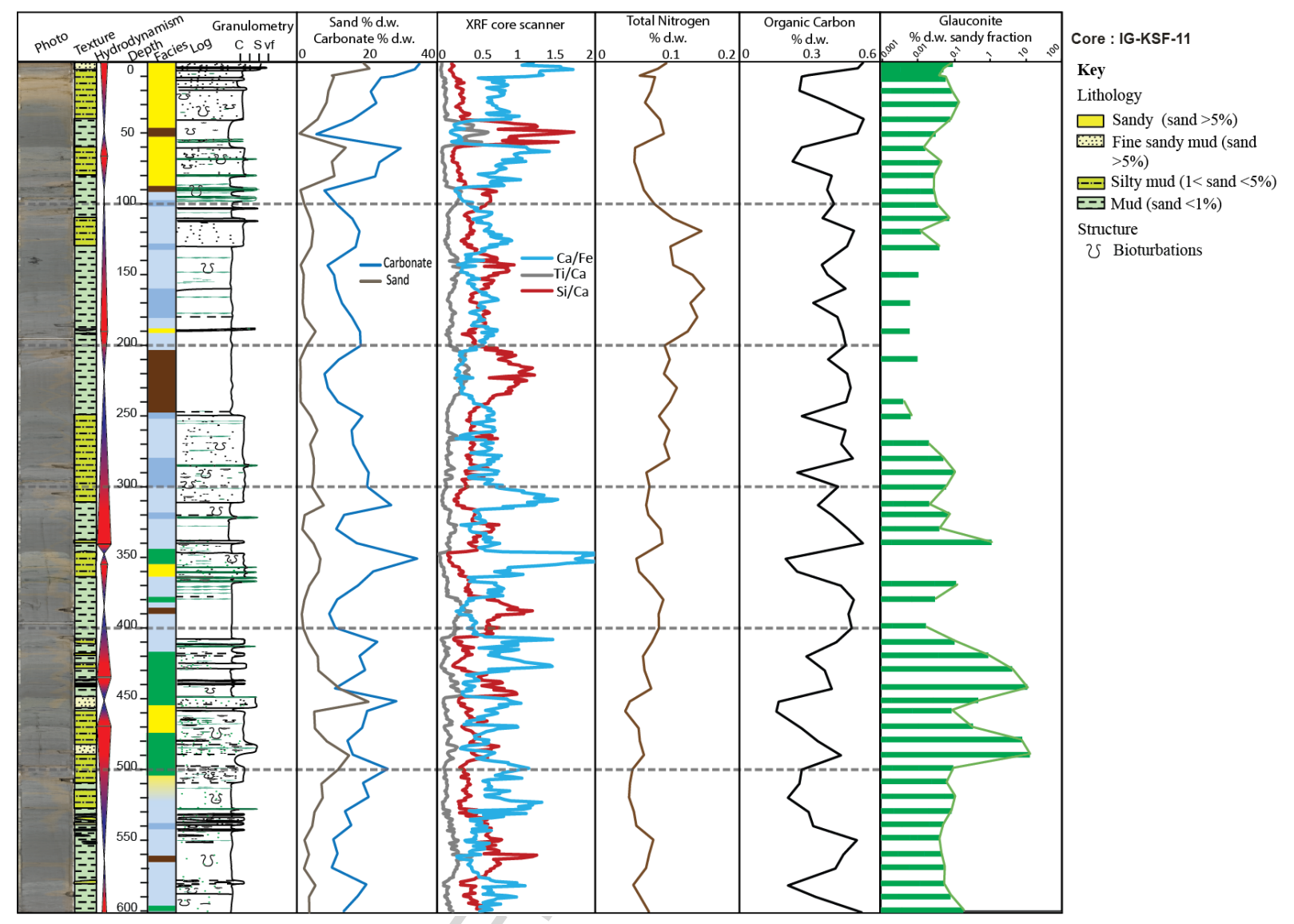

Fig. 13 


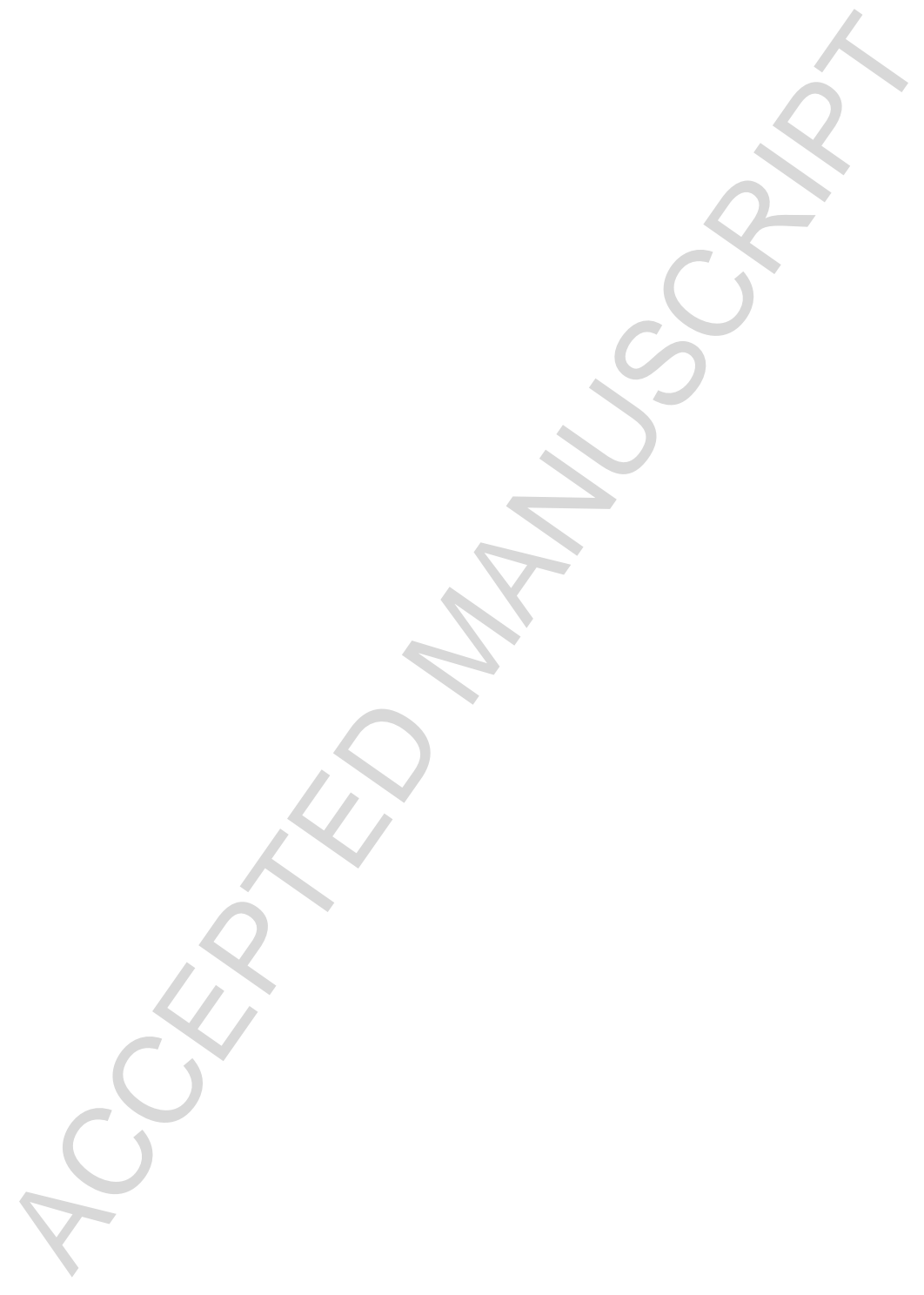


Table 1: Presentation of the different water masses and their characteristics in the equatorial Atlantic Ocean.

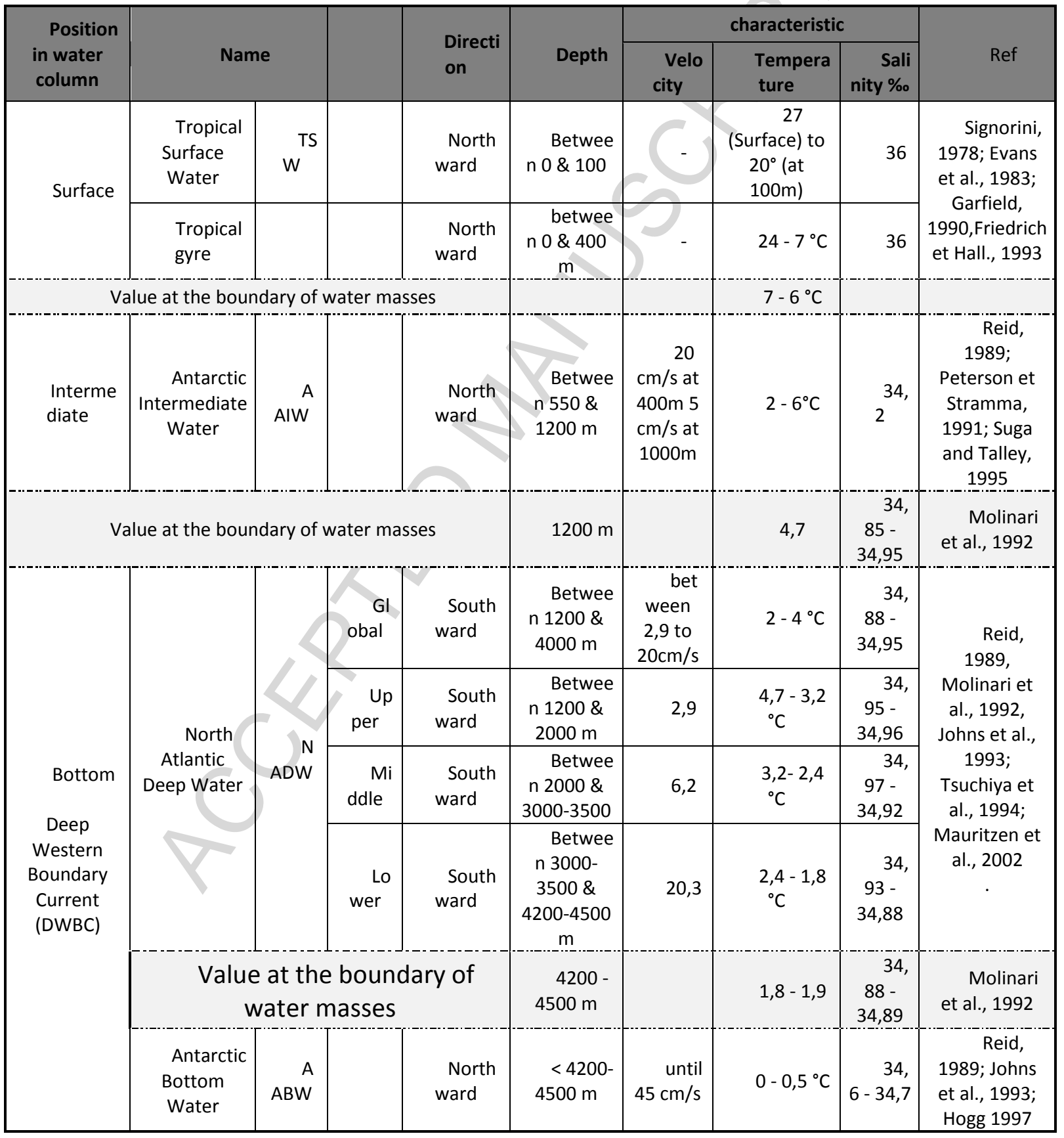


Table 2: Radiocarbon dates for well-preserved Globigerinoides sp. fractions from samples collected from core IG-KSF-11. The calibrated ages were calculated by using Calib 7.0.4 with the Marine 09 calibration curve (Reimer et al., 2013).

\begin{tabular}{|c|c|c|c|c|c|c|c|}
\hline \multirow{2}{*}{$\begin{array}{l}\text { De } \\
\text { pth } \\
\text { core } \\
(\mathrm{cm})\end{array}$} & \multirow[t]{2}{*}{ Core } & \multirow[t]{2}{*}{ Material } & \multirow{2}{*}{$\begin{array}{l}\text { Lab } \\
\text { code }\end{array}$} & \multirow{2}{*}{$\begin{array}{l}\text { Age }^{14} \mathrm{C} \\
(\mathrm{yr} B P)\end{array}$} & \multicolumn{3}{|c|}{$\begin{array}{c}1 \text { sigma calibrated } \\
\text { age } \\
\text { (yr cal. BP) }\end{array}$} \\
\hline & & & & & $\min$ & $\begin{array}{l}\mathrm{ma} \\
\mathrm{x}\end{array}$ & $\begin{array}{l}\text { aver } \\
\text { age }\end{array}$ \\
\hline 0 & $\begin{array}{r}\text { IG- } \\
\text { KS-11 }\end{array}$ & $\begin{array}{l}\text { Globigerinoides } \\
\text { sp. }\end{array}$ & $\begin{array}{l}\text { Poz- } \\
68066\end{array}$ & $\begin{array}{c}13930 \pm 80 \\
\text { BP }\end{array}$ & $\begin{array}{c}14 \\
201\end{array}$ & $\begin{array}{r}14 \\
466\end{array}$ & $\begin{array}{c}14 \\
334\end{array}$ \\
\hline $0^{13}$ & $\begin{array}{r}\text { IG- } \\
\text { KS-11 }\end{array}$ & $\begin{array}{l}\text { Globigerinoides } \\
\text { sp. }\end{array}$ & $\begin{array}{r}\text { Poz- } \\
68067\end{array}$ & $\begin{array}{c}37100 \pm 800 \\
\text { BP }\end{array}$ & $\begin{array}{c}38 \\
560\end{array}$ & $\begin{array}{r}39 \\
974\end{array}$ & $\begin{array}{r}39 \\
267\end{array}$ \\
\hline 31 & $\begin{array}{r}\text { IG- } \\
\text { KS-11 }\end{array}$ & $\begin{array}{l}\text { Globigerinoides } \\
\text { sp. }\end{array}$ & $\begin{array}{r}\text { Poz- } \\
68115 \\
\end{array}$ & $\begin{array}{c}42700 \pm 1500 \\
\text { BP }\end{array}$ & $\begin{array}{c}42 \\
287 \\
\end{array}$ & $\begin{array}{r}45 \\
138 \\
\end{array}$ & $\begin{array}{r}43 \\
713 \\
\end{array}$ \\
\hline $2^{45}$ & $\begin{array}{r}\text { IG- } \\
\text { KS-11 }\end{array}$ & $\begin{array}{l}\text { Globigerinoides } \\
\text { sp. }\end{array}$ & $\begin{array}{l}\text { Poz- } \\
68116\end{array}$ & $\begin{array}{c}48000 \pm 3000 \\
\text { BP }\end{array}$ & - & - & - \\
\hline $2^{58}$ & $\begin{array}{r}\text { IG- } \\
\text { KS-11 }\end{array}$ & $\begin{array}{l}\text { Globigerinoides } \\
\text { sp. }\end{array}$ & $\begin{array}{r}\text { Poz- } \\
68117\end{array}$ & $\begin{array}{c}39700 \pm 1100 \\
B P\end{array}$ & $\begin{array}{l}40 \\
675\end{array}$ & $\begin{array}{r}42 \\
385\end{array}$ & $\begin{array}{r}41 \\
530\end{array}$ \\
\hline $\begin{array}{l}60 \\
0\end{array}$ & $\begin{array}{r}\text { IG- } \\
\text { KS-11 }\end{array}$ & $\begin{array}{l}\text { Globigerinoides } \\
\text { sp. }\end{array}$ & $\begin{array}{r}\text { Poz- } \\
58858\end{array}$ & $\begin{array}{c}28400 \pm 200 \\
\text { BP }\end{array}$ & $\begin{array}{r}29 \\
479\end{array}$ & $\begin{array}{r}30 \\
059\end{array}$ & $\begin{array}{c}29 \\
769\end{array}$ \\
\hline
\end{tabular}




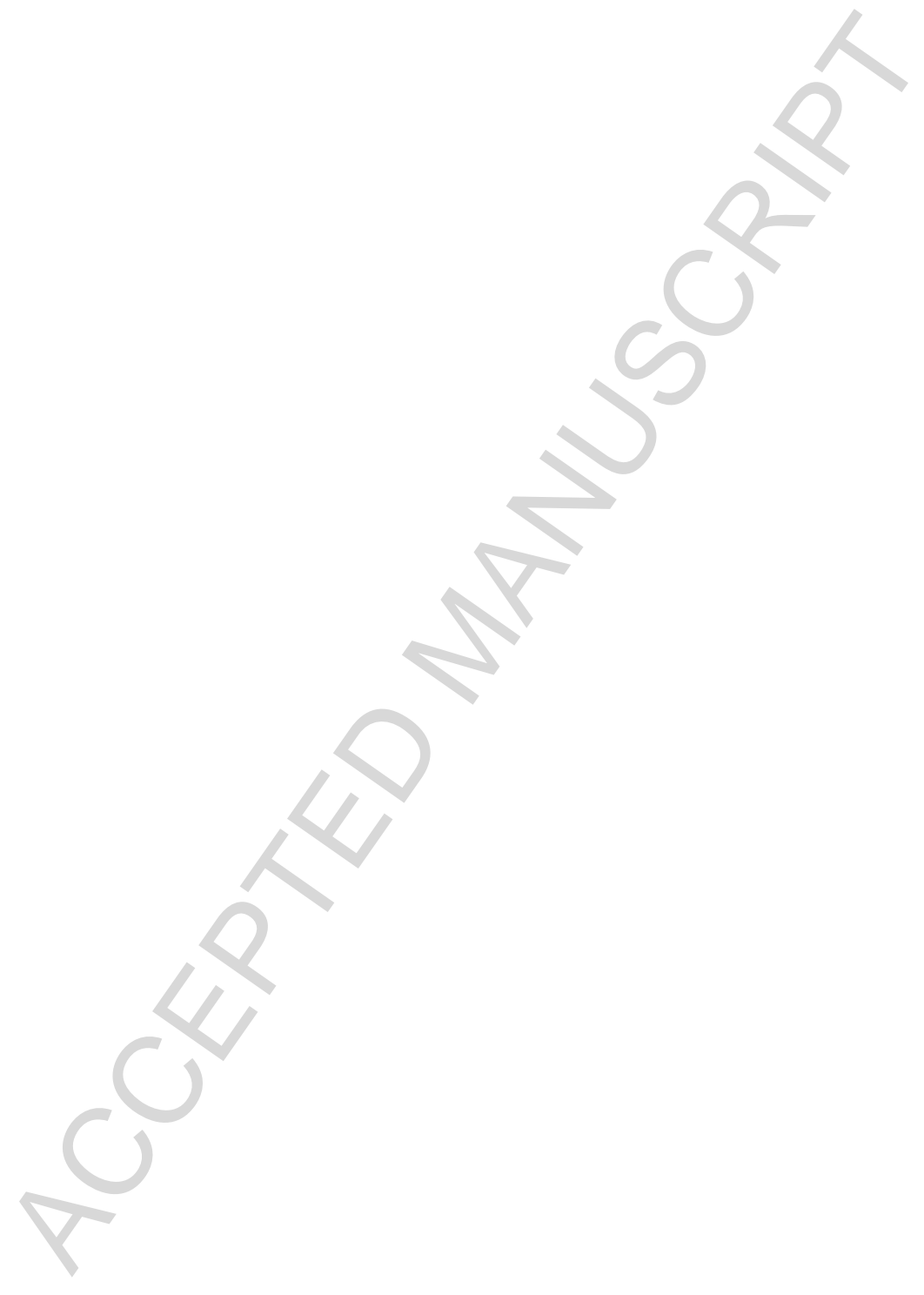


Table 3: Sedimentary facies identified from the observation of IGUANES cores and classified as a function of the hydrodynamic regime.

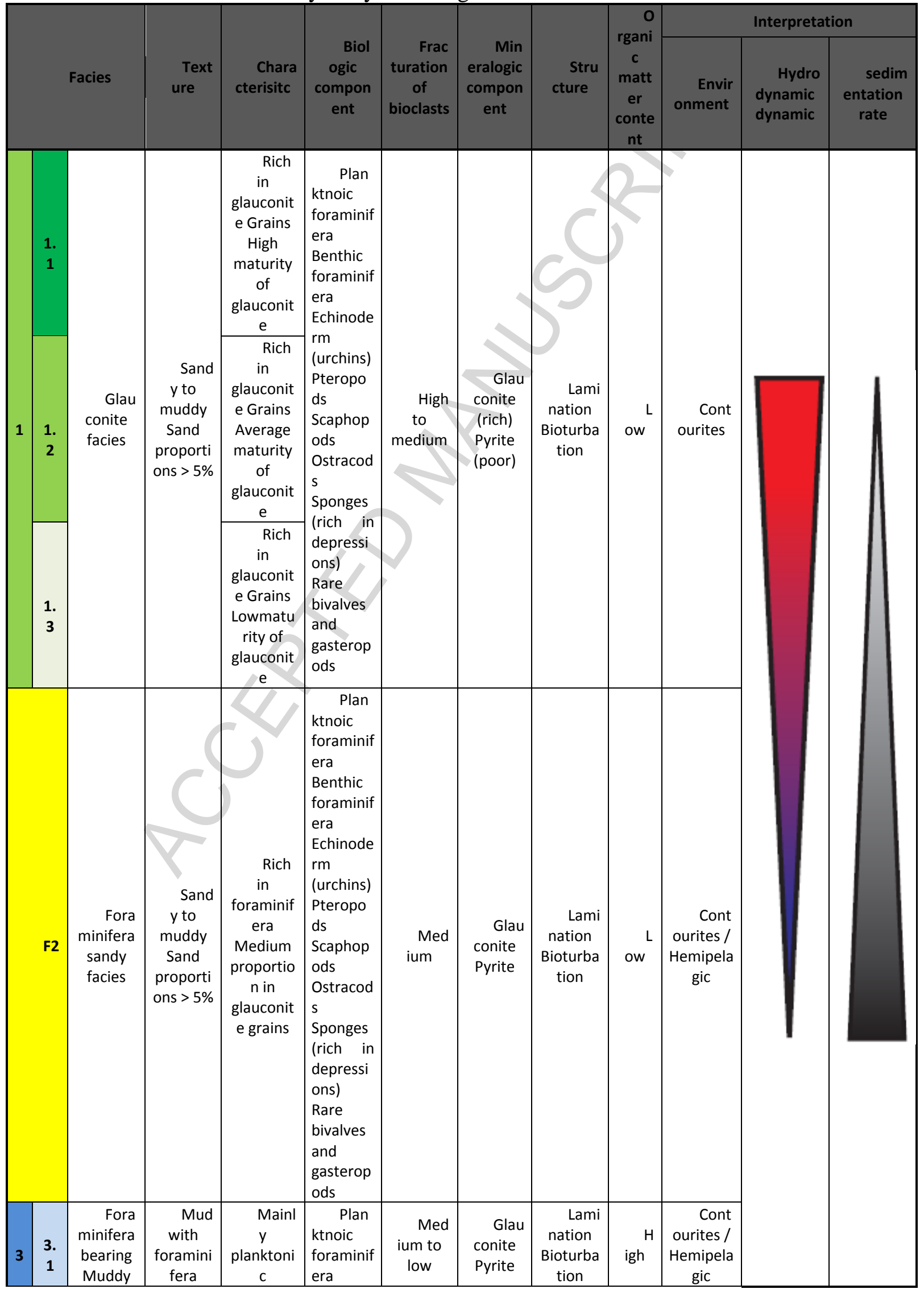




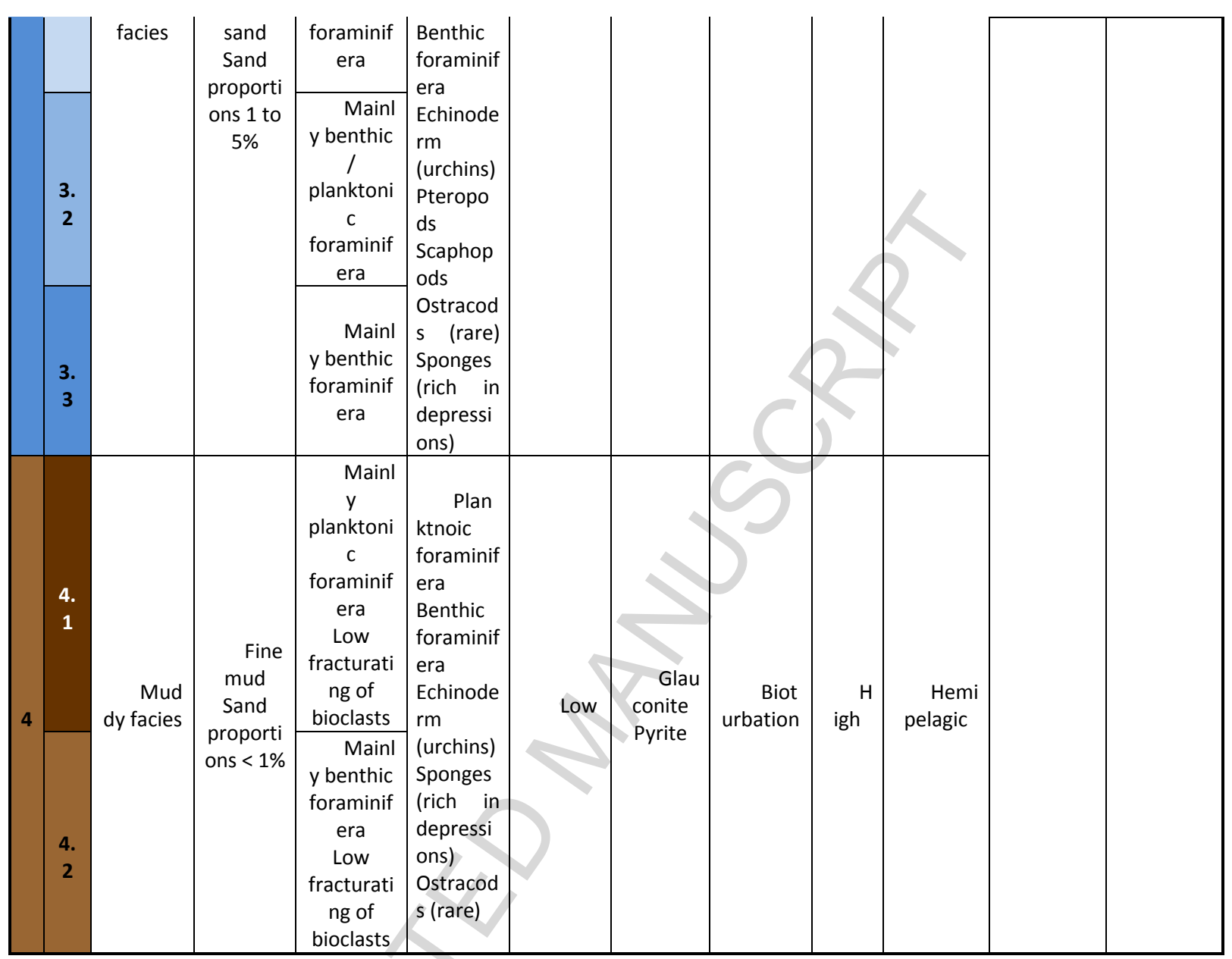

